\title{
Kredi ve Kredi İşlemlerinin Hukuki Açıdan Değerlendirilmesi
}

\author{
Legal evaluation of credit and credit transactions
}

\author{
Senar ÇAĞIRGAN TUNCER ${ }^{1}$ \\ Yasin ULUSOY 2 a \\ ${ }^{1}$ Pamukkale Üniversitesi, Hukuk Fakültesi, Denizli. senart@pau.edu.tr \\ ${ }_{2}^{2}$ Pamukkale Üniversitesi, İktisadi ve İdari Bilimler Fakültesi, Denizli. yulusoy@pau.edu.tr \\ a Yazışılan yazar/Corresponding author
}

\begin{abstract}
Özet
En basit tanımıyla satın alma gücünün, belli bir süre sonra ödenmesi taahhüt edilerek, faiz karşılı̆̆ında bir başkasının kullanımına bırakılması olan kredi, günümüzde bankacılık işlemleri içinde önemli bir yer teşkil etmektedir. Kredi; satın alma gücü să̆lamak amacryla, maddi ya da maddi olmayan bir malın veya bir miktar para yahut garanti sözleşmesi ve kefalette söz konusu olduğu gibi risk için sorumluluk yüklenilmesini kapsar. Bu itibarla kredi türlerini en genel çerçevesi ile bankalar tarafından, nakdi bir ödeme yapılarak kredi alana satın alma gücü sağlayan nakdî krediler ile nakdi bir ödemede bulunmaksızın bir riskin gerçekleşmesi durumunda sorumluluğun üstlenilmesi şeklinde gayri nakdi krediler olmak üzere ikiye ayırabiliriz. Bu ayırım çerçevesinde kredi türlerinin hukuki niteliğ $i$ ve uygulanacak hükümler farklılaşmaktadır. Banka ile bir gerçek veya tüzel kişi arasında kredi ilişkisi tek bir kredinin açılmasına ilişkin kredi sözleşmesi veya birden çok kredinin açılmasını içine alan kredi açma sözleşmesinin imzalanması suretiyle doğmaktadır. Kredi sözleşmesin veya kredi açma sözleşmesinin içeriğ $i$ kredi türüne göre farklılı gösterir. Bunun yanında kredi veya kredi açma sözleşmesi ile kurulan kredi ilişkisinde, kredinin kullanma şekli, ödemenin ne şekilde gerçekleşeceği gibi hususlar açısından, kredinin işleyeceğ $i$ hesabın türü de önem taşımaktadır.
\end{abstract}

Anahtar kelimeler: Kredi, Kredi sözleşmesi, Bankacılık, Kredi işlemleri, Genel işlem koşulları

JEL kodlart: K00, M00.

\begin{abstract}
Credit may be simply defined as the transfer of purchasing power to the use of another person in return for interest to be paid after a certain period of time accounts for an important part of the banking operations today. Credit involves both tangible or intangible assets, or a certain amount of money or guarantee contract and bail in order to create purchasing power, and the assumption of liability for the risk. In this respect, we can categorize the credit types into two as cash credits that provide the borrower with purchasing power through the gain of a cash payment and non-cash credits that is the assumption of liability in the realization of a certain risk, without gaining any cash payments. The legal character of the loan types and the provisions to be applied vary in line with this categorization. The credit relationship between the Bank and a real or legal person is established through the signing of a credit agreement including the opening of a single loan or a credit-opening agreement that involves the opening of multiple loans. The content of the credit agreement or credit-opening agreement varies according to the type of the credit. In addition, in the credit relationship established through the credit or credit opening agreement, the type of the account to which the loan will be deposited is also important in terms of the way in which the loan is used and how the payment will be made.
\end{abstract}

Keywords: Credit, Credit Agreement, Banking, Credit Transactions, General Transaction Conditions

JEL codes: K00, M00. 


\section{GİRIŞ}

Kredi işlemlerinin tarihsel kökenleri çok eski çağlara uzanmakla birlikte, özellikle sanayi devrimi ile başlayan süreçte işletmelerin artan finansman ihtiyaçları ile daha da önem kazanmıştır. Son yıllarda tüketici kredilerinin kullanılmasında yaşanan artış ile birlikte sadece ticari işletmeler için değil aynı zamanda bireysel tüketiciler açısında da kredi işlemleri ön plana çıkmıştır. Bu çalışma ile kredi türleri arasındaki farklar vurgulanmaya çalışılırken kredi sisteminin işleyişi de bir bütün olarak verilmeye çalışılmıştır. Kredi açma sözleşmesinin hukuki niteliği tartışmalı olduğu için bu konu ayrı bir başlık altında ele alınarak karşılaştırmalı olarak değerlendirilmiştir.

\section{KREDİ KAVRAMI VE KREDİ TÜRLERİ}

\subsection{Kredi Kavramı}

Kredi kelimesi, Latincede "inanmak", "güvenmek" anlamına gelen "credere” sözcügünden gelmiş ve dilimizde "itibar"a olarak tercüme edilmiştir (Tekinalp, 1988: 351; Onur, 1957; Urganc1, 1982: 56).

Kredinin Türk Hukuku açısından yasal bir tanımı verilmemiştir. İktisat bilimi açısından ise çeşitli tanımlar yapılmıştır. Buna göre iktisadi açıdan kredi, "hazır bir satın alma gücünün kullanılmasından belli bir süre bir başkası lehine vazgeçilerek bu gücün ona teslim edilmesi (Tekinalp, 1998: 350)"; "hazır bir servetin ileride vücut bulacak bir servetle mübadelesi (Kahyaoğlu, 1969: 3; Etem, 1934: 7)”; “hali hazırda başlayan ve gelecekte sona erecek olan mübadele" (Onur, 1957: 3), "muayyen bir miktardaki satın alma gücünün, belli bir vade sonunda geri verilmek vaadi ile bedel (faiz) karşıllğında bir gerçek veya tüzel kişinin kullanımına bırakmak" (Köklü, 1967: 11) olarak çeşitli şekillerde tanımlanmıştır. Yapılan tanımlardan yola çıkılarak kredi, satın alma gücünün, belli bir süre sonra ödenmek vaadiyle, bir bedel karşılığında (faiz) bir başkasının kullanımına bırakılması olarak tanımlanabilir.

\subsection{Kredinin Unsurları}

Kredinin tanımından hareketle kredinin unsurlarını şu şekilde sayabiliriz:

İlk olarak belirli bir satınalma gücünün verilmesi sayılabilir. Satın alma gücü, maddi ya da maddi olmayan bir malın veya bir miktar para ve hatta garanti sözleşmesi ve kefalette söz konusu olduğu gibi risk için sorumluluk yüklenilmesi de "satın alma gücü" kavramı içine sokmak gerekir (Tekinalp, 1988: 352).

Diğer bir unsur olarak, kredinin belirli bir süre için verilmesi başka bir deyişle, geçici karakteri sayılabilir. Satın alma gücü geçici bir süre için devredilmiş olup bu kararlaştırılan sürenin hitamında iade edilmek üzere kredi verilmiştir (Tekinalp, 1988: 350; Köklü, 1967: 11; Kahyaoğlu, 1969: 3).

Satın alma gücünün, sahibi tarafından belli bir süre ile iade edilmek üzere devri bir diğer unsur olarak "güven" unsurunu ortaya çıkartmaktadır (Tekinalp, 1988: 350; Köklü, 1967: 12; Kahyaoğlu, 1969: 4; Kocaimamoğlu, 400). Gerçekten kredi veren kredi alanın iade vaadine güvenmekte, itimat etmektedir. Güven unsurunun getirdiği diğer bir unsur risk olarak sayılabilir (Kocaimamoğlu, 400). Ancak gelişen iktisadi hayatta, güven ile risk unsuru genelde

a 818 sayılı mülga Borçlar Kanunu 399 ve 400. maddelerinde "itibar mektubu" ve "itibar emri” kavramlarındaki itibar kelimesi esas itibariyle "kredi” kelimesinin karşılığı olarak kullanılmıştır. 
kredi muamelelerinden doğan iade vaatlerinin yerine getirilmesinin, özellikle bankalarca sağlam garantilere bağlanması sonucu daha arka planda kalmaktadır (Köklü, 1967: 2).

Son unsur olarak faizi sayabiliriz. İleride yapılacak ödemeye, hali hazırdaki ödeme gücünden daha çok değer verilmesi ve bu suretle bunların mübadele edilebilmesi için, ödeme vaadinin, vazgeçilen değerden fazla olması gerekir ki; bu fazlalığa faiz denir (Zarakoğlu, 1972: 20). Bu itibarla satın alma gücünü devralan, bunun karşılığında faiz ödemek zorundadır. Ancak özellikle son yıllarda, çeşitli mal ve hizmetlerin satışını kolaylaştırarak piyasaya hareket getirmek amaciyla bankalar belli limitlere ve vadeye kadar faizsiz tüketici kredisi vermektedir. Özelikle otomobil piyasasında, bankalarca faizsiz olarak satış finansman kredisi veya bağlı kredi $^{b}$ olarak anılan krediler tesis edilmektedir. Burada satıcı firma tarafından faiz ve komisyon yüklenilmektedir.

\subsection{Kredinin İktisadi Hayat Açısından Faydalanı ve Rolü}

Kredi; bir tedavül aracı vazifesini görmektedir (Kocaimamoğlu, 400; Kahyaoğlu, 1969: 10; Etem, 1934: 17). Kredi sayesinde, özellikle ticari muamelelerde alışverişler, nakit para nakline gerek kalmadan süratle ve masrafsız, yapılabilir (Kahyaoğlu, 1969: 10; Etem, 1934: 17). Kredi, hali hazırda var olan ve fakat atıl bulunan sermaye ve tasarrufların, iş sahasına aktarılmasını ve bu suretle iktisadi faaliyetlerin devamını ve genişlemesini sağlar (Kocaimamoğlu, 400; Kahyaoğlu, 1969: 10; Zarakoğlu, 1972: 23). Ayrıca büyük teşebbüslerin kurulması ve yaşamasına imkân vermektedir. Kişilerin kullanmadıkları birikimleri bu büyük teşebbüslerin sermaye ihtiyaçlarını karşılamada yardımcı olmaktadır (Kahyaoğlu, 1969: 11; Zarakoğlu, 1972: 23). Kredi, mal alım - satım hızını artırır. Özellikle tüketici kredisi, kredi kartı, kredili satışlar gibi imkânlar, üretimi ve piyasayı hızlandırarak hareketlendirmektedir (Zarakolu, 1972: 23.). Kredi; müteşebbisleri, teşebbüslerini, birikimde bulunmak için uzun bir zaman geçmesini beklemeksizin derhal hayata geçirmelerini sağlar (Kocaimamoğlu, 401; Kahyaoğlu, 1969: 11).

\subsection{Kredi Türleri}

5411 sayılı Bankacılık Kanununda da kredinin yasal bir tanımı verilmemekle birlikte, kredi sınırlarının çizilmesinde bankanın hangi işlemlerinin kredi sayılacağı 48.maddesinde belirtilmiştir.

Krediler; 5411 sayılı Bankacılık Kanunu'nun 48 maddesi 1. fıkrasında; bankalarca verilen nakdî krediler ile teminat mektupları, kontrgarantiler, kefaletler, aval, ciro, kabul gibi gayrinakdî krediler ve bu niteliği haiz taahhütler, satın alınan tahvil ve benzeri sermaye piyasası araçları, tevdiatta bulunmak suretiyle ya da herhangi bir şekil ve surette verilen ödünçler, varlıkların vadeli satışından doğan alacaklar, vadesi geçmiş nakdî krediler, tahakkuk etmekle birlikte tahsil edilmemiş faizler, gayrinakdî kredilerin nakde tahvil olan bedelleri, ters repo işlemlerinden alacaklar, vadeli işlem ve opsiyon sözleşmeleri ile benzeri diğer sözleşmeler nedeniyle üstlenilen riskler, ortaklık payları ve Kurulca kredi olarak kabul edilen işlemler izlendikleri hesaba bakılmaksızın bu Kanun uygulamasında kredi sayılacağ düzenlenmiştir.

\footnotetext{
b Bağlı kredi veya finansman kredisi olarak belirttiğimiz kredi, ancak tahsis edildiği alanda kullanılabilen; satıcı, tüketici ve finans kurumu arasında üçlü bir ilişki kuran bir tüketici kredisi çeşididir. Burada banka ve satıcı belli bir malın satışının sağlanması amacıyla, tüketiciye finansman sağlamak açısından birlikte hareket etmektedir. Ayrıntılı bilgi için bkz. İnal, T, 2002: 254 vd
} 
Birinci fıkrada belirtilenlere ilâve olarak, kalkınma ve yatırım bankalarının finansal kiralama yöntemiyle sağladığı finansmanlar ile katılım bankalarının taşınır ve taşınmaz mal ve hizmet bedellerinin ödenmesi suretiyle veya kâr ve zarar ortaklığı yatırımları, taşınmaz, ekipman veya emtia temini veya finansal kiralama, mal karşılığ vesaikin finansmanı, ortak yatırımlar veya benzer yöntemlerle sağladıkları finansmanlar da bu Kanun uygulamasında kredi sayılır (Bankacılık Kanunu 48/II).

Kredileri çeşitli açılarından farklı ayrımlara tabi tutmak mümkündür (Tekinay vd., 1993: 156). Bunlar:

- Nitelikleri açısından; nakdi ve gayrinakdi krediler

- Kredinin kullanım şekline göre, doğrudan ve dolaylı krediler

- Teminata bağlanması veya bağlanmaması açısından açık veya teminatlı krediler

- Türk parasına veya yabancı paraya dayalı açılan krediler

- Kredinin vadelerine göre; kısac, orta, uzun vadeli krediler

- Kredinin kaynağına göre; sözleşmeden ve kanundan doğan krediler

- Kredinin kulanım alanına göre; belli bir alanda kullanılan kredilerd, serbest krediler şeklinde yapılabilir (Tekinalp, 1988: 359; İnal, 2002: 268; Kostakoğlu, 1996: 104; Kostakoğlu, 2003).

Kredi türleri, nitelikleri açısından nakdi ve gayrinakdî krediler olmak üzere ikiye ayrilmaktadir.

\section{A .NAKDİ KREDILER}

Banka tarafından nakit ödeme yapılmak suretiyle verilen krediler nakdi kredi olarak tanımlanır. Bu itibarla kredi kartı hesabı suretiyle kullandırılan kredi, tüketici kredileri veya eski kanunda mal kredisi ${ }^{\mathrm{e}}$ olarak tanımlanan kredi de aslında nakdi kredidir.

\section{a. Sabit Vadeli Para Ödüncü}

Sabit vadeli para ödüncü kredisinde banka parayı bir defada kredi alana verir, kredi alan ise almış olduğu bu para ödüncünü tek defada veya taksitler halinde kararlaştırmış oldukları vadede geri öder (Tekinalp, 1988: 359; Kostakoğlu, 1996: 106; Kostakoğlu, 2003: 929; Akyol, 2001: 80). Bu kredi sözleşmelerinde cari hesap şeklinde çalışmaz. Bu nedenle kredinin yenilenmesi, döner çalışması söz konusu değildir (Tekinalp, 1988: 359; Akyol, 2001: 80.). Banka krediyi bir defada verir, kredi alan ödeme yapmakla belli limite kadar tekrar kredi çekme imkânı yoktur. Kredi belli bir limite kadar cari hesap şeklinde açılmamıştır. Bu sebeple kredi alanın ödemeler yaparak krediyi döner olarak kullanması mümkün değildir (Tekinalp, 1988: 359).

Bu kredi sözleşmesinin hukuki mahiyeti Borçlar Kanunu 386 ve devamı maddelerinde düzenlenen tüketim ödüncü (karz) sözleşmesidir (Tekinalp, 1988: 359; Reisoğlu, 1988: 283.). Bu nedenle bu kredi sözleşmesine tüketim ödüncü (karz) sözleşmesi hükümleri uygulanır.

\footnotetext{
${ }^{\mathrm{c}}$ Kısa vadeli krediler genellikle likidite sorununun çözümlenmesi için çekilen kredilerdir.

${ }^{\mathrm{d}}$ Belli bir alanda kullanılan krediler; zira1, ticari ve tüketici kredileri olarak ayrılabilir.

${ }^{\text {e }}$ Mal kredisi, bankanın müşterisine değil de, müşterisinin alışveriş yaptığı satıcıya nakit ödemede bulunmak suretiyle verdiği kredidir. Genelde Ziraat Bankası'nın, çiftçilerin tohum, gübre vs. ihtiyaçları için verdiği kredi bu türdür. Bkz. Tekinalp, 1988: 157. Bağlı tüketici kredisinde de yine kredi müşteriye tüketim malı satan satıcıya ödenmektedir.
} 
Kredinin konusunu teşkil eden tüketim ödüncü sözleşmesi, rızai bir sözleşme olup sözleşmenin kurulabilmesi için taraf iradelerinin uyuşması yeterlidir. Ayrıca tüketim ödüncünün konusu olan paranın mülkiyetinin kredi alana geçirilmesine gerek yoktur (Nart, 2014: 235; Zevkliler, 2002: 273; Zevkliler, 2002: 280). Paranın mülkiyetinin geçirilmesi, sözleşmeden doğan bir borcun yerine getirilmesidir (Zevkliler, 2002: 280). Bankanın sözleşmeden doğan bu borcu, eğer taraflar bir tarih kararlaştırmamışlar ise sözleşmenin kurulması ile muaccel olurf.

Kredi alan parayı kredi konusu ödüncü almakla yükümlüdür. Kredi sözleşmesinde kesin vade öngörülmesi sebebiyle kredi alan ödemeleri bu vadelerde yerine getirmediği takdirde temerrüde düşer (Tekinalp, 1988: 360).

Sabit vadeli para ödüncü şeklindeki nakdi kredilere örnek olarak özellikle son yıllarda yaygınlaşan şekilde kullanılan tüketici kredileri örnek olarak gösterilebilir.

\section{b. Senet veya Emtia Avansı (Lombard Kredisi)}

Kredi açan banka tarafından, kredi alanın bir menkul veya bir alacak hakkı yahut ortaklık hakkını temsil eden bir kıymetli evrak veya senetsiz ya da adi senede bağlanmış bir alacağını rehnetmesi karşılığında ona açmış olduğu kredidir (Akyol, 2001: 80; Tekinalp, 1988: 360-361.). Burada açılan kredi, banka lehine rehnedilen emtia veya kıymetli evrakla temin edilir (Zarakoğlu, 1972: 38.).

Bankalar genellikle paraya çevrilmesi kolay mallar ile bono, poliçe, çek gibi kambiyo senedi yahut tahvil, hisse senedi ve Hazine ya da banka bonosu gibi menkul kıymetler karşılığı olarak kredi açarlar (Tekinalp, 1988: 361; Zarakoğlu, 1972: 38). Banka kredi açarken menkul kıymetlerin de paraya çevrilme derecesine bakar (Köklü, 1967: 42). Bunun yanında bankalar rehnedilen emtia ve kıymetli senetlerin değerinin ancak bir kısmını kredi verir. Çünkü piyasa ve borsadaki fiyat dalgalanmaları sebebiyle bu değerlerin kıymetinin düşmesi ve bu surette zarar etmesi riski bu şekilde karşılanmaktadır (Zarakoğlu, 1972: 38; Kahyaoğlu, 1969: 24).

Lombard kredisi genelde cari hesap şeklinde işler. Kredi alan elindeki malını veya kıymetli evrakını bankaya rehnetmeleri karşılığında banka da ona kredi açar. Bu kredinin genelde kısa vadeli kredi olarak açıldığı görülmektedir (Zarakoğlu, 1972: 38; Kahyaoğlu, 1969: 24).

Senet ve emtia avansı (lombard) kredisi hukuki nitelik itibariyle, para ödüncü kredisidir (Tekinalp, 1988: 361). Genellikle cari hesap şeklinde açılan bu kredi, Borçlar Kanunu 386 ve devamı maddelerinde düzenlenen tüketim ödüncü sözleşmesine ilişkin hükümlerle birlikte, Ticaret Kanunu 89 ve devamı maddelerinde düzenlenen cari hesaba ilişkin hükümlere de tabi olmaktadır (Tekinalp, 1988: 362). Lombard kredisinin belli bir limite kadar cari hesap şeklinde açılması sonucu ödediği oranda tekrar kredi çekmesi şeklinde "döner " kredi kullanımı bu kredinin hukuki mahiyetinin tüketim ödüncü sözleşmesi olmadığı şeklinde yorumlanabilmektedir (Tekinalp, 1988: 362). Tekinay'a göre bu tür kullanım lombardın ödünç

\footnotetext{
${ }^{\mathrm{f}}$ Borçlar Kanunu 390. maddeye göre; ödünç alan sözleşme yapıldıktan sonra acze düşerse veya sözleşme yapılmadan önce acze düşmekle birlikte ödünç veren bu durumu sözleşme yapıldıktan sonra fakat ödünç konusu şey verilmeden önce öğrenirse sözleşmeden doğan borcunu yerine getirmekten kaçınabilir. Ayrıntılı bilgi için bkz. Zevkliler, 2002: 284. Ancak sabit vadeli para ödüncü şeklinde kredi açan bankanın BK. 310. maddeki bu imkandan yararlanma imkanı olmamalıdır. Çünkü bankalar kredi sözleşmelerini yaparken kredi alanın ödeme durumunu ayrıntısıyla incelemiş olmalıdırlar. Bkz. Tekinalp, 1988:360.
} 
sözleşmesis olma niteliğini kaldırmaz ${ }^{\text {h }}$ Bu kullanım tarzı lombardın değil, cari hesabın özelliğidir. Ayrıca bu kredi sabit vadeli ve kullanmakla tükenen ödünç sözleşmesi şeklinde de açlabilir demektedir (Tekinalp, 1988: 362).

Senet ve emtia Avansı (Lombard) kredisi; mal avansı(lombard1), kambiyo senedi avansı (lombard1), menkul değer avansı (lombard1) olarak ayılır (Tekinalp, 1988: 361). Burada rehnedilen şeye göre ayrım yapılmıştır. Bu işlemdeki rehin; menkul rehni, alacak üzerinde rehin, kıymetli evrakın rehni ve teminat amacıyla temlik şeklinde olabilir (Tekinalp, 1988: 361).

\section{c. Kıymetli evrakın iskontosu ve İştira Yolu ile Kredi Verilmesi}

İskonto; bankanın,vadesi henüz gelmemiş bir kambiyo senedinii (bono, çek, poliçe), vade gününe kadar işleyecek olan faizlerini, komisyon ve masraflarını düşerek, bakiyeyi peşin olarak hamiline ödemek suretiyle iktisap etmek olarak tanımlanabilir (Akyol, 2001: 80; Tekinalp, 1988: 362; Yüksel, 1986: 213; Köklü, 1967: 33; Zarakoğlu, 1972: 40; Kahyaoğlu, 1969: 20; Kölemezli, 1983: 7; Yılmaz, 1992: 427). Henüz vadesi gelmemiş bulunan bir kambiyo senedinin, faiz miktarının indirilerek peşin olarak ödenmesi, hamilin ihtiyacı olan paranın peşin olarak ödenmesi suretiyle bir kredi fonksiyonu görmektedir (Tekinalp, 1988: 362; Kahyaoğlu, 1969: 20). Kambiyo senedinde yapılan kesintiye iskonto denir (Akyol, 2001: 80; Tekinalp, 1988: 362; Yüksel, 1986: 213; Köklü, 1967: 33; Zarakoğlu, 1972: 40; Kahyaoğlu, 1969: 20. Bankalar faiz, masraflar ve komisyondan oluşan iskonto kesintisi kazancı yanında, bir kısım parayı müşterinin hesabında bloke ederek zorunlu mevduat oluşturmaktadır. Bkz. Akyol, 2001: 22).

İştira ise, senedin düzenleme yeri ve ödeme yeri aynı olan bir kambiyo senedinin henüz vadesi gelmeden, banka tarafından faiz ve masraflar düşüldükten sonra bedelinin bankaca peşin olarak ödenmesidir (Kölemezli, 1983: 7.). İskonto ile iştira aynı işlemler olmakla beraber aralarındaki tek fark, senedin iskontosunda ödeme yeri ile düzenleme yerinin aynı, senet iştirarında ise farklı yerler olmasıdır (Tekinalp, 1988: 362.).

Bankalar da iskonto ettikleri kambiyo senetlerinin vadelerini beklemek yerine, likitide sağlamak açısından, Merkez Bankasına iskonto verebilirler. Bu senetlerin ikinci defa Merkez Bankası tarafından iskontoya kabul edilmesine mükerrer iskonto yahut reeskont denir (Yüksel, 1986: 213; Köklü, 1967: 34).

İskonto kredisinin hukuki mahiyeti tartışmalıdır. Bu itibarla iskontonun satım, ödünç veya atipik bir ödünç yahut alacağın temliki olduğunu savunanlar vardır. Bu yazarlara göre; iskonto işlemi hukuken ne bir ödünç ne de bir kredi açma sözleşmesidir (Yüksel, 1986: 214.). Banka senetleri rehin olarak değil; hamiline yazılı senetlerde zilyetliğin devri, nama yazılı senette alacağın temliki ve zilyetliğin devri, emre yazılı senetlerde ciro ve zilyetliğin devri yolu ile almaktadır. Bu işlem bankanın senetleri satın almasıdır (Tekinalp, 1988: 363; Yüksel, 1986:

\footnotetext{
g Tüketim ödüncü sözleşmesinde, sözleşme konusunu teşkil eden ödüncün mülkiyetini bir defada karşı tarafa geçirmektedir. $\mathrm{Bu}$ itibarla sabit vadeli para ödüncü kredisinde, açılan kredi son limitine kadar kredi alana verilmektedir. Kredi alanın bu kredinin belli kısmını kullanma, geri yatırıp tekrar çekme gibi imkanları bulunmamaktadır.

h Tüketim ödüncü sözleşmesiyle cari hesap birbirinden farklı olmakla birlikte, tüketim ödüncü şeklinde (para ödüncü) alınan kredi tutarı banka nezdinde alacaklı bir cari hesaba yatırılarak, kredinin kullanımı bu cari hesap üzerinden izlenebilir. Bkz. Yüksel, 1986: 211. Kanımızca bu açıdan cari hesabın "döner" kullanımı, lombard olarak da adlandırılan senet ve emtia senedinin karz akdi niteliğini kaldırmaz. Ayrıca borçlu cari hesabı bulunan banka müşterisi de bu hesap dahilinde, döner olarak lombard kredisi çekebilecektir.

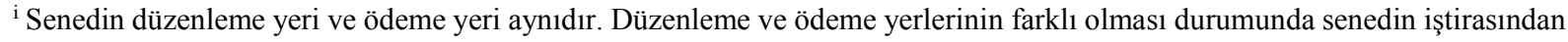
bahsedilir. Hatır senetleri iskonto/iştiraya kabul edilmez.bkz. Tekinalp, 1988: 363.
} 
214). Bu satımın konusu bu senetlerin temsil ettiği haklardır ve diğer menkul satımından tek farkı senedin devri için gereken prosedürdür (Yüksel, 1986: 214). İskonto edilen senet iskonto alanın mülkiyetinden tamamen çıkmakta, satım sözleşmesinin ifası olarak bankaya devredilmektedir. Yoksa kredi alanın krediyi geri ödemesini sağlamak amacıyla teminat olarak alınmamıştır (Tekinalp, 1988: 363). Senedin tahsil edilememesi durumunda, banka tarafından iskonto alana geri verilmesi de yine bu işlemin satım olduğu savını zedelemez. Çünkü banka bu senetleri tahsil edeceği inancı ile almaktadır. Taraflar, tahsil edilemediği takdirde senedin geri verileceği konusunda anlaşmışlardır. Kaldı ki; emre yazılı senetlerde; hamilin, aynı zamanda ciranta olan iskonto alana başvurması kanundan doğmaktadır (Tekinalp, 1988: 363).

İskonto veya iştira işleminin ödünç veya atipik ödünç olduğunu savunanlar ise; satım görüşünün iskontonun bir kredi işlemi olma niteliğini tam olarak açıklamadığını, bankanın senetleri satın alarak kredi veremeyeceğini, zaten burada senetlerin ifa yerine değil ifa uğruna kabul edilmiş olduğu için senetler tahsil edilemediğinde geri dönmektedir diyerek görüşlerini savunmaktadırlar.

Kanımızca, iskonto/iştira işleminin hukuki niteliği ödünç sözleşmesidir. Burada kambiyo ilişkisinin altında aslında bir ödünç ilişkisi yatmaktadır. Nasıl ki bir borcu temin amacıyla teminat için bir kambiyo senedi düzenlenip veriliyorsa, kambiyo senedi düzenlenip verilmesi de aynı şeydir. Burada alınan para ödüncüne teminat olarak senet bankaya verilmektedir. Senedin temelinde yatan ilişki ödünç ilişkisidir.

\section{d. Forfait (Uzun Vadeli Alacak Satın Alınması) İşlemi ile Kredi Verilmesi}

Fransızca bir kelime olan "forfait", götürü ve götürü olarak satın almak anlamına gelir. Forfait mal ve hizmet ihracatından doğan, tahsil günü gelmemiş (müeccel) alacakların, banka tarafından, alacak tahsil edilememiş olsa bile temlik edene başvurmamak kaydı ile satın alınmasıdır (Tekinalp, 1988: 363). Bu alacaklar bono ve poliçeye bağlanmış olup ayrıca bir bankanın aval vermesi veya kabul etmesi ile kuvvetlendirilmiştir(Tekinalp, 1988: 364).

Forfait kredisinde; ihracatçı (satıcı) firma, satıp teslim etmiş olduğu mal karşılığında, ithalatçı (alıc1) firmadan, bedel karşılığında bono veya poliçe almıştır. Vadesi henüz gelmemiş bu senetler, bir banka tarafından aval verilmek veya kabul edilmeki suretiyle güçlendirilerek ve satıcı (ihracatçı) firma tarafından forfait kredisi verecek bankaya devir eder. Forfait veren banka, vadeye kadar işleyecek olan faiz, tahsil ve transfer komisyonlarını ve kur risklerini hesaplayarak senet bedelinden kesinti yapark. Burada dikkat edilmesi gereken husus; banka, poliçe veya bononun bedeli ödenmediği takdirde, iskonto kredisinin aksine, kredi alan (ihracatçı-satıcı) firmaya başvurmamayı kabul etmiştir. Burada, satıcı firma, bedel karşılığında senedi bankaya devretmekle senedin cirantası olmuştur ve senedin bedelinin

\footnotetext{
j Banka tarafindan aval verilmesi veya senedin kabul edilmesi, gayrinakdi kredi türlerindendir. Aval kredisinde banka, müşterisinin bono, poliçe gibi kambiyo senetlerinden doğan borcuna aval vermektedir. "Kabul kredisi"nde ise; banka müşterisinin kendi üzerine poliçe çekmesine izin verip, bunu kabul etmeyi taahhüt etmiştir. Aval veya kabulle güçlenen ve birinci sınıf bir garantiye sahip olan senetlerin, iskonto edilmesi, forfait kredisi alması veya ifa amaciyla alacaklıya verilmesi sağlanmış olur. Bkz. Tekinalp, 1988: 401,402; Akyol, 2001:82.

${ }^{\mathrm{k}}$ Bkz. Tekinalp, 1988:364. Yapılan bu kesintiye forfait iskontosu denir.
} 
ödenmemesinden ciranta olarak kanunen kendisine başvurma imkânı1, forfait ile ortadan kaldırılır (Tekinalp, 1988: 364).

Forfait yatırım mallarının ihracatının finansmanında kullanılmakta olup, beş yıl gibi uzun vadeli bir kredi türüdürm ${ }^{m}$. Forfaitin hukuki niteliği de iskontoda olduğu gibi satım mı, ödünç mü olduğu hususunda tartışmalıdırn .

\section{e. Factoring (Alacak Satın Alınması ve Takibi) İşlemi ile Kredi Verilmesi}

Vadeli satış yapan işletmelerin, bu satışlardan doğan alacaklarını, tahsil için gereken işlemleri yapması ve tahsil etmesi için factor ${ }^{\circ}$ adı verilen finans kurumu veya bankaya ${ }^{p}$ devretmesi işlemine factoring denir. Alacağını factoring kuruluşu veya bankaya ciro veya temlik eden müşteri alacağını belli bir komisyon karşılığında almaktadır (Akyol, 2001: 16.). Ancak factor banka veya finans kurumu sadece kredili müşterinin hesabını tutmak ve hukuki işlemleri yapmak suretiyle, alacağı devir almadan da factoring işlemlerini yürütebilirq.

İskonto, forfaiting ve factoring birbirine yaklaşan kavramlar olmakla birlikte aralarında şu farklar olduğu söylenebilir: Factoring ile forfait alacağın satın alınması olması ile birlikte factoring tüketim malları, forfaiting yatırım mal ve hizmetleri ile ilgili olması, bunlardan factoringin kısa vadeli veya vadesiz, forfaiting uzun vadeli kredi olması yanında factoring, alacağın tahsili için icra takibi ve dava açacak şekilde düzenlenmiştir. Kanımızca forfaiting uzun vadeli bir kredi olması sebebiyle bankanın ancak kuvvetlendirilmiş "birinci sınıf" ticari senet karşılığ forfait işlemine girişmesi bir başka farkı oluşturur. İskontodan farkı ise factoringde kredi açılması için factora kıymetli evrakın tevdiinin zorunlu olmamasıdırr.

Factoring, gerçek ve görünürde factoring olmak üzere ayrilır(Akyol, 2001: 16; Tekinalp, 1988: 366). Gerçek factoringde factor, alacağın tahsil edilememesi riskini üstlenir, alacak tahsil edilemese de müşterisine alacağının karşılığını öder(Akyol, 2001: 16; Tekinalp, 1988: 366). Bu itibarla forfaitinge benzer. Görünüşte factoringde ise alacağın borçludan tahsil edilememesi durumunda, factor müşterisine rücu edebilir. Burada tahsil edilememe riski müşteride kalmaktadır(Akyol, 2001: 16; Tekinalp, 1988: 366).

Factoring sözleşmesi karma muhtevalı bir sözleşme niteliği taşır (Akyol, 2001: 16; Tekinalp, 1988: 366). Şöyle ki, factor, kendisine temlik edilen alacağın tahsilini yaptığı için hizmet sözleşmesi unsuru bulunmaktadırs. Hizmet işlemlerine vekalet hükümleri uygulanır. Müşteri tarafından alacağın factor'a devrinde ise satım veya ödünç olduğu hususunda tartışmalar vardır (Akyol, 2001: 20). Tekinay'a göre; gerçek factoring satım, görünürde factoring ise

\footnotetext{
${ }^{1}$ Poliçede kabul ya da ödeme gerçekleşmediği takdirde keşidecien başliyarak, ciro silsilesindeki her ciranta ve varsa bunların avalistleri, kendilerinden sonra gelenlere karş1 poliçenin ödenmemesinden sorumludur.(TTK. 591 vd) Bonoya da TTK.690. madde gereğince, iki senedin farklılıkları dolayısıyla bazı maddeler müstesna kalmak üzere, poliçeye uygulanan hükümler bonoya da uygulanacağından,aynı hüküm bonoda da geçerlidir. Ayrıntılı bilgi için bkz. Poroy, 1999: 183, 237.

m Tekinalp, 1988:364. Factoring ise, tüketim mallarının ihracatının finansmanında kullanılıp, kısa vadeli kredi türüdür.

n İskonto kredisinde bu hususun üzerinde durulduğu için tekrar ele alınmayacaktır.

o İngilizce bir kelime olan factor, sözlük anlamı simsardır.

${ }^{\mathrm{p} B a n k a l a r}$ genelde factoring işlemini kurdukları ayrı ortaklıklarla yürütmektedirler.

q $\mathrm{Bu}$ durum gizli factoring olarak adlandırılmaktadır. Alacak ancak ödenmeme halinde alacağın takibi ve tahsili için factora geçirilmektedir.Tekinalp, 1988: 366.

${ }^{\mathrm{r}}$ Factoring firmaları nakit ihtiyacı olan müşterisi, borçlusundan henüz senet almadan factora başvurabilir. Bu şekildeki factoring işleminin Türkiyede uygulaması yoktur. Bkz. Akyol, 2001: 17.

s Akyol'a göre factoring sözleşmesinin amacı kredi açamak ya da kredi almak değil, müşteri açısından senedinin tahsilini sağlamak, factor içinse senedin tahsili karşıllı̆ 1 faiz ve komisyondan oluşan kazanç elde etmektir.bkz. Akyol, 2001: 24 . Bu itibarla müşteri ile factor arasında bir hizmet ilişkisi vardır. Bkz. Akyol, 2001: 19,20; Tekinalp, 1988: 366.
} 
alacağın temliki ile güvence altına alınmış bir ödünçtür. Kanımızca; bu görüşte, görünürde factoringde factor, alacağı tahsil edemediği takdirde müşterisine yönelerek yaptı̆̆ geri isteyebilmesinden dolayı bu alacağın factor tarafından açılan kredinin bir teminatı olduğu ve "ifa yerine" değil "ifa uğruna" alacağın temlik edildiğinden hareket edilmektedir.

\section{f. Finansal Kiralama ( Leasing ) İşlemi İle Kredi Verilmesi}

Anayurdu Anglo Amerikan hukuku olan ve Amerika Birleşik Devletlerinde "leasing" kelimesiyle ifade edilen bu kurum, daha sonra Kıta Avrupası ülkelerinde de benimsenmiştir (Zevkliler, 2002: 293).

"Leasing" kavramını, bizim hukukumuzda "finansal kiralama" olarak isimlendirilmiştir. Finansal Kiralama, Faktoring ve Finansman Şirketleri Kanunu'nun 3. madesine göre; "bir finansal kiralama sözleşmesine dayalı olmak koşuluyla, bu Kanun veya ilgili mevzuatı uyarınca yetkilendirilen kiralayan tarafından finansman sağlamaya yönelik olarak bir malın mülkiyetinin kira süresi sonunda kiracıya devredilmesi; kiracıya kira süresi sonunda malın rayiç bedelinden düşük bir bedelle satın alma hakkı tanınması; kiralama süresinin malın ekonomik ömrünün yüzde sekseninden daha büyük bir bölümünü kapsaması veya finansal kiralama sözleşmesine göre yapılacak kira ödemelerinin bugünkü değerlerinin toplamının malın rayiç bedelinin yüzde doksanından daha büyük bir değeri oluşturması hâllerinden herhangi birini sağlayan kiralama işlemi" şeklinde tanımlanmaktadır.

Finansal Kiralama işlemini kısaca şu şekilde özetleyebiliriz:

İşletmesinde ihtiyaç duyduğu bir malı veya teknolojiyi işletmesine getirmek isteyen firma, bu yatırımı öz kaynaklarını kullanmak veya kredi almak yerine, finans kurumuna başvurarak gereksinim duyduğu bu makine veya teknoloji, vs.nin onun satın almasını ve kullanımın belli bir süre sözleşmeden dönmemek koşuluyla üretim faaliyetlerinde kullanmak üzere kendisine devrini ister (Zevkliler, 2002: 294; Köteli, 1983: 64).

Leasingde, leasing sözleşmesine konu olan şeyin mülkiyeti leasing kurumunda kalmakla birlikte, her türlü hasarın riski, vergi ve mükellefiyetler kullanıcıya aittir. Bu açıdan kira sözleşmesinden ayrılır. Maldan yaralanma süresi, o malın ekonomik ömrüne eşit bir süre olarak belirlenir (Köteli, 1983: 64).

Leasing sözleşmelerinde belli bir süre sözleşmeden dönülmesi mümkün olamamaktadır. Bu safhaya dönülmez safha denilir.

Leasing süresinin sona ermesinden sonra, kullanıcı, mal ekonomik değerini yitirmişse, bunu leasing kurumuna terk ederek sözleşme yükümlülüklerinden kurtulabilir. Eğer hala verimliyse, sözleşmenin yenilenmesini kararlaştırabilirler. Bu durumda bilinen kira akdi söz konusu olur. Bunların yanında kullanıcı malın mülkiyetini elde edebilir yahut leasingli mal satılarak satış bedeli düşülmek suretiyle yeni bir mal için leasing sözleşmesi yapılabilir (Kölemezli, 1983: 67-68).

\section{B. Gayri Nakdi Krediler}

Gayri nakdi krediler; nakdi kredilerin aksine, bankanın para ödemeksizin bir riskin gerçekleşmesi halinde, ortaya çıkacak olan zararın sorumluluğunu üstlendiği bir kredi çeşididir (Akyol, 2001: 81; Tekinalp, 1988: 367; Kostakoğlu, 2003: 929; Kostakoğlu, 1996: 106.). Nakit kullanımı olmayan bu tür kredilerde banka, müşterisine bir süre için bir satın alma gücü 
sağlamaktadır (Tekinalp, 1988: 367). Banka bir sorumluluk yüklendiği için gayrinakdi kredisine "yükümlülük kredisi" veya "sorumluluk kredisi" de denilmektedir (Akyol, 2001: 81; Tekinalp, 1988: 367).

Gayrinakdi kredilerde banka gibi güçlü bir kurumun, müşterisi ile bir sözleşme akdetmiş bulunan kişiye, müşterisinin borcunu vadesinde ifa etmemesi halinde zararını tazmin edeceği hususunda garanti vermesi, bu kişinin borcun ifası hususundaki şüphelerini ortadan kaldırarak, bankanın müşterisine belirli bir vade tanımasını sağlayacaktır. Bu şekilde banka müşterisine bir satın alma gücü sağlamakla kredi vermiş olmaktadır (Tekinalp, 1988: 367).

Gayrinakdi kredilerde sorumluluk üstlenilen zararın gerçekleşmesi durumunda banka için bu kredi, olası riskden nakdi riske dönüşür (Karacan, 1987: 204). Bundan sora banka yüklendiği sorumluluğu nakdi olarak ödeyecektir (Tekinalp, 1988: 368).

Gayri nakdi kredilerde; temel ilişki, karşılık ilişkisi ve teminat (bedel) ilişkisi olmak üzere üç köşeli bir ilişki vardır (Tekinalp, 1988: 370-371). Şöyle ki; banka müşterisi bankadan, bir komisyon karşılığında, sözleşme yapacağı kişiye karşı bir riskin gerçekleşmesi halinde yüklendiği borcu veya ortaya çıkan zararı tazmin garantisi vermesini talep etmektedir (Tekinalp, 1988: 370). Böylece banka, bankanın müşterisi ve onunla sözleşme yapan kişiden oluşan üçlü bir ilişki ortaya çıkmaktadır (Tekinalp, 1988: 370). Banka müşterisi ile onunla sözleşme yapan kişi arasındaki ilişki temel ilişkidir (Tekinalp, 1988: 370). Banka ile müşterisi arasındaki ilişki de bir kredi açma sözleşmesine dayanan bir kredi ilişkisidir. Son olarak banka ile, temel ilişkide belirttiğimiz sözleşen arasındaki ilişki de teminat ilişkisidir. Bu ilişki kefalet, garanti sözleşmesi veya kabul, ciro, aval kredisi gibi gayrinakdi krediler olabilir (Tekinalp, 1988: 371).

Gayrinakdi kedileri garanti kredisi, kefalet kredisi, kabul kredisi, aval kredisi, ciro kredisi olarak sinıflandırabiliriz.

\section{a.Garanti Kredisi}

Garanti kredisinde banka, müşterisinin kurduğu veya kuracağı bir hukuki ilişkide, müşterisinin bu hukuki ilişkiden doğan borcunu yerine getirmemesi veya korkulan bir olayın meydana gelmesi rizikosunu üstüne almaktadır (Tekinalp, 1988: 372; Akyol; 2001: 81). Bu itibarla banka müşterisinin riskini üstlenmektedir. Bankanın garanti sözleşmesinden doğan yükümlülüğü asıl borçtan bağımsızdır (Tekinalp, 1988: 372; Tandoğan, 1985: 601; Yavuz, 2002: 803).

Banka, müşterisi ile sözleşecek kişiyle akdettiği garanti sözleşmesi ile müşterisi ile aktedeceği sözleşmeden doğan riski bağımsız bir taahhütle üzerine almakta ve bu suretle bu kişiyi müşterisi ile sözleşme yapmaya teşvik ve ikna etmektedir (Tekinalp, 1988: 372; Yavuz, 2002: 803.). Bu itibarla banka üçüncü kişiyle garanti sözleşmesi yapmak suretiyle müşterisine gayri nakdi kredi sağlamaktadır (Tekinalp, 1988: 372).

Banka, müşterisi ile sözleşecek kişiyle akdettiği garanti sözleşmesinde bahsedilen risk, müşterisinin borcunu ifa etmemesi veya sözleşmeden doğan bir edimin ifa edilmemesi ile alakasız olarak bir olayın gerçekleşmesi tehlikesi olabilir. Garanti sözleşmelerinde, garanti verenin yüklenmiş olduğu risk kavramina beklenilmeyen hal ve kaza da girer (Tandoğan, 1985: 608; Yavuz, 2002: 810). Bu husus kendini kaçınılan bir olayın garanti edilmesinde bu olayın kaza ve beklenilmeyen hal sonucu ortaya çıkmasında gösterir (Tandoğan, 1985: 608) 
Garanti sözleşmesinde kefaletin aksine sorumluluk sınırının belirlenmesi geçerlik şartı değildir (Tandoğan, 1985: 608)

Garanti kredisinde, garanti veren bankanın garanti sözleşmesinden doğan yükümlülüğü asıl borçtan bağımsızdırt. Bu unsur garanti sözleşmesini kefaletten ayırmaktadır. Kefalette bankanın sorumluluğu asıl borca fer'i niteliktedir (Tandoğan, 1985: 609; Yavuz, 2002: 810.). Bağımsızlık unsuru sebebiyle bankanın garanti sözleşmesinden doğan yükümlülüğü, asıl borcun varlığına, geçerliliğine, devamına, dava ve takip konusu edilebilir olmasına bağlı değildir (Tekinalp, 1988: 373; Tandoğan, 1985: 609; Yavuz, 2002: 810). Bu nedenle banka, müşterisine ait olan def'i ve itirazları ileri süremez (Tekinalp, 1988: 373).

Garanti sözleşmesinin unsurları arasında ivazsızlığın bulunup bulunmadığı tartışmalıdır. Bazı yazarlara göre, ivazsızlı̆ıın garanti sözleşmesinin asli unsurlarından olduğu yönündedir. Bu görüşe göre garanti edenin rizikoyu üzerine alması, üçüncü kişiyi bir hukuki ilişki içine girmek şeklindeki bir hareket tarzına yöneltmek, ikna etmek olmalıdır (Tekinalp, 1988: 373; Tandoğan, 1985: 611; Yavuz, 2002: 803). Bu amaç olmaksızın ivaz sağlamak amacıyla risk üstlenilmişse bu sözleşme garanti özleşmesi niteliğini taşımaz (Tekinalp, 1988: 373; Tandoğan, 1985: 611; Yavuz, 2002: 803). Ayrıca garanti sözleşmesinin tek tarafa borç yükleyen bir sözleşmedir denilmektedir (Tekinalp, 1988:373; Tandoğan, 1985: 611; Yavuz, 2002: 803). Bankaların garanti kredisi karşılı̆̆ında müvekkilinden komisyon alması esasen, banka ile kendisinden garanti kredisi talep eden müşterisi arasındaki vekâlet ilişkisinden ${ }^{u}$ doğmaktadır (Tandoğan, 1985: 611). Yoksa garanti sözleşmesinin karşı tarafından alınan bir ivaz değildir. Bu nedenle garanti sözleşmesi dişında bir ödemedir (Tekinalp, 1988: 373; Tandoğan, 1985: 611). Bazı yazarlar ise ivazlı olabileceğini savunmaktadırlar.

Garanti sözleşmesi çeşitli açılardan bir takım tasniflere tabi tutulabilir:

- Rizikonun niteliğine göre garanti sözleşmeleri genel olarak kefalet benzeri garanti sözleşmeleri(teminatı amaçlayan garanti sözleşmeleri) ile saf garanti sözleşmeleri (yöneltmeyi amaçlayan garanti sözleşmeleri) olarak ikiye ayrılır (Tekinalp, 1988: 373; Tandoğan, 1985: 601; Yavuz, 2002: 804-805).

Kefalet benzeri garanti sözleşmesinde, garanti verenin teminat vermek amaciyla temel ilişkideki alacaklıya karşı, temel ilişkideki asıl borçtan bağımsız olarak ${ }^{v}$, edimin yerine getirilmesinden sorumlu olmayı yüklenmektedir (Tandoğan, 1985: 601; Yavuz, 2002: 804.). Burada asıl borca ilişkin ifa borcunun yerine getirilmemesi durumunda doğan zarardan sorumluluk söz konusudur (Tekinalp, 1988: 374).

Saf garanti sözleşmesi, garanti verenin, garanti alanı belirli bir davranışa yöneltmek amacıyla, bu davranışın sonucunda bu kişinin girmiş olduğu risklerin tamamen veya kısmen garanti veren tarafından yüklenilmesidir (Tandoğan, 1985: 602-603; Yavuz, 2002: 806-807). Burada kefalet benzeri garantinin aksine garanti alan ile sözleşeni arasında bir borç ilişkisi yoktur (Tekinalp, 1988: 374; Tandoğan, 1985: 605; Yavuz, 2002: 810). Örneğin belli bir miktar kar

\footnotetext{
${ }^{\mathrm{t}}$ Sorumluluk yüklenilen edimin tanımının, kapsamının ve muacceliyetinin veya asıl borçtan kaynaklanan def'i ve itirazların ileri sürülemeyeceğinin garanti sözleşmesinde belirtilmesi bağımsızlık unsurunun varlığına delalet sayılmaktadır. Buna karşılık asıl borca yollama yapılması karine olarak fer'iliğe yorumlanmaktadır. Ayrıntılı bilgi için bkz. Tekinay, s.380.

" Karşılık ilişkisi olarak belirttiğimiz banka ile garanti kredisi alan müşterisi arasındaki ilişkiye vekalet hükümleri uygulanır. Bkz. Tekinalp, 1988:382.

${ }^{v}$ Borçlu olup olunmadığına yahut, borcun dava veya icra takibi ile takip edilip edilmediğine bakılmaksızın...
} 
garantisi verilen ortaklık ile müstakbel ortaklar arasında henüz bir borç ilişkisi yoktur (Tekinalp, 1988: 374; Tandoğan, 1985: 605). Bu itibarla saf garanti verenin borcu, edimi garanti edilenin borcundan tamamen bağımsızdır (Tandoğan, 1985: 605; Yavuz, 2002: 810). Saf garanti sözleşmesinde garanti verenin borcu, bir borç ilişkisi ile ilgili olmadan, yani her hangi bir edimin yerine getirilmemesine bağlanmaksızın, korkulan bir olayın gerçeklemesine bağlanmıştır (Tekinalp, 1988: 372).

- Garanti alanın talebinin türüne göre ilk talepte kaydını ${ }^{w}$ içeren garanti sözleşmeleri, adi garanti mektupları ve bir belge ibrazının gerekli olduğu garanti mektupları olarak üçe ayırabiliriz:

Bankanın garanti alanın rizikonun gerçekleştiğini ispatlamasını isteyemediği gibi bunu kendisi de araştıramayacağı garanti sözleşmeleri ilk talepte kaydını içeren garanti sözleşmeleridir (Tekinalp, 1988: 372). Burada banka garanti alanın ilk talebinde garanti ettiği meblağı ödeyecektir .

Adi garanti sözleşmesinde ise; garanti alanın rizikonun gerçekleştiğini ispat etmesi veya bankanın bunu araştırma yetkisinin olması yahut bir şartın öngörülmesi söz konusudur (Tekinalp, 1988: 372).

Bankanın bir belgenin sunulması halinde ödeme yapmayı kabul etmesi halinde bir belge ibrazının gerekli olduğu teminat mektuplarından bahsediliry.

- Mektup veya sözleşme şeklinde düzenlenen garantiler:

Garantiler mektup şeklinde olabileceği gibi mektup şeklinde de düzenlenebilir.

Mektup şeklindeki garantiler arasında teminat mektubu önemli yere sahiptir. Teminat mektuplarının hukuki niteliği uzun süre tartışılmakla beraber, 1969 tarihli içtihadı birleştirme kararında garanti sözleşmesi olduğu belirtilmiştir (Tekinalp, 1988: 375).

Garanti sözleşmesi İsviçre-Türk Hukukunda düzenlenmediği için bu sözleşmenin hukuki niteliği tartışmalıdır. Bazı yazarlar, garanti sözleşmesinin kredi ve teminat fonksiyonlarından hareketle, banka garantisini teminat akreditifi olarak nitelemişlerdir (Tekinalp, 1988: 377). Ancak öğretide hakim görüşe göre garanti sözleşmesi, üçüncü kişinin fiilini taahhüt olarak kabul edilmektedir (Tekinalp, 1988: 378; Yavuz, 2002: 803). Yargıtay'ın görüşü de bu yöndedirz. BK. 128. maddede üçüncü kişinin fiilini taahhüt "üçüncü bir kişinin fiilini başkasına karşı üstlenen, bu fiilin gerçekleşmemesinden doğan zararı gidermekle yükümlüdür" şeklinde düzenlenmekle esas itibariyle sadece kefalet benzeri garanti sözleşmelerini kapsamaktadır (Tekinalp, 1988: 378). Ancak Tekinay'a göre BK. 128. maddedeki temel amaç garanti etmektir. Bu itibarla bu hükmün temel amacından hareketle

\footnotetext{
w İlk talepte kaydı asıl borçtan bağımsızlı̆̆ı teşkil ettiğinden çoğu zaman garanti sözleşmesine delalet eder meğerki sözleşmenin hükümlerinden fer'ilik niteliği anlaşılmasın. Ayrıntılı bilgi için bkz. Tandoğan, 1985: 618; Tekinalp, 379.

${ }^{x}$ Bir görüşe göre; ilk talepte ödeme kaydına dayanılarak yapılan ödeme talebinde, talebin dayanaksız ve keyfi olduğu açık ise, hakkın kötüye kullanılmasını teşkil ettiğinden bahisle banka, ödemeden kaçınabilir. Yargıtay da "teminat mektubu muhtevasının istenmesi herhangi bir şarta bağlanmamış olsa dahi haklı bir sebebe dayanmadan karşı tarafın zararını mucip olacak şekilde talep edilmesi hakkın kötüye kullanılması teşkil eder" demek suretiyle bu yönde bir karar oluşturmuştur. Ayrıntılı bilgi için bkz. Tandoğan, 1985: 619; Tekinalp, s. 384,385 .

y Örnek olarak senedin ödenmediğinin protesto çekilmesi ile kanıtlanması, maldaki ayıbın bir raporla belgelendirilmesi... vb Ayrıntılı bilgi için bkz. Tekinalp, 1988:375.

z Yarg. İç.Bir. Kar. S:4/6, T:13.12.1969
} 
korkulan olayın gerçekleşmesi halinde ortaya çıkan zararın yüklenilmesi şeklindeki saf garanti sözleşmelerini geniş yorumla bu madde içine almak gerekir (Tekinalp, 1988: 378-379; Yavuz, 2002: 803-804).

Yavuz'a göre ise; başkasının fiilini taahhüt ile garanti sözleşmesi arasında ortak bir alan olmakla birlikte, başkasının fiilini taahhüt mahiyetinde olmayan garanti sözleşmeleri olduğu gibi, garanti sözleşmesi niteliğinde olmayan başkasının fiilini taahhüt sözleşmeleri de vardıraa. Yavuz'a göre garanti sözleşmesi kendisine göre yapısı olan isimsiz bir sözleşme niteliği göstermektedir (Yavuz, 2002: 804). Kanımızca garanti sözleşmesinin kanundaki düzenlenen sözleşmelerle tam olarak nitelendirilememesi sebebiyle isimsiz bir sözleşme olarak kabulü yerindedir.

\section{b. Kefalet Kredisi}

Banka, asıl borçlunun borcunu ödememesi halinde, asıl borçlunun beklediği menfaati, başka bir deyişle asıl borcun ifa edilmemesinden doğan zarar yani müspet zararr ${ }^{\mathrm{bb}}$ yüklenmektedir (Tekinalp, 1988: 397; Tandoğan, 1985: 499; Reisoğlu, 1992: 7; Yavuz, 2002: 765). Burada banka, asıl borçlu olan müşterisinin edimini yerine getirmesinden alacaklıya karşı sorumlu olmayı kabul etmekle, müşterisine gayrinakdi kredi sağlamış olmaktadır (Tekinalp, 1988: 397).

Kefilin borcu bir tazminat borcu olması nedeniyle, para ile ölçülebilen, para ile temin edilebilen bütün verme veya yapmama borçlarına kefil olunabilir (Tandoğan, 1985: 500; Tekinalp, 1988: 397; Zevkliler, 2002: 391; Yavuz, 2002: 766). Borçlunun borcunu yerine getirmemesinden doğan zarar, para ile belirlenen bir tazminatın ödenmesiyle giderilebilir olmalıdır (Reisoğlu, 1992: 7). Bu nitelikteki borçlunun şahsının önemli olduğu borçlara dahi kefil olunabilir (Tandoğan, 1985: 500).

Kefalet sözleşmesinde kefilin borcu, garanti sözleşmesinin aksine fer'i niteliktedir. Kefalet, asıl borcun varlığı ve geçerliliği halinde hüküm ifade eder. Asıl borç ne şekilde sona ererse ersin kefalet de sona erecektir (Tandoğan, 1985: 496; Reisoğlu, 1992: 2; Tekinalp, 1988: 397; Aral, 1997: 236). Kefalet akdinin fer'i nitelikte olması; kefile asıl borçludan fazla bir mükellefiyet yüklenemez, borç asıl borçlu için muaccel olmadan kefil için muaccel olmaz, asıl borç şarta bağlı iken kefilin borcu şartsız olamaz, asıl borcun ortadan kalkması kefalet borcunu da ortadan kaldırır, kefalet alacağı asıl borçtan bağımsız temlik edilemez gibi bir takım sonuçları doğurur (Ayrıntılı bilgi için bkz. Tandoğan, 1985: 497; Reisoğlu, 1992: 2; Aral, 1997: 236-237).

Kefalet akdi, kural olarak ivazsız, tek tarafa borç yükleyen bir sözleşme olmakla birlikte, ivazsızlık fer' ilik unsurunun aksine kefaleti diğer sözleşmelerden ayıran asli bir unsur değildir (Tandoğan, 1985: 496; Reisoğlu, 1992: 5-6; Tekinalp, 1988: 398). Kefil olacak kişiyi ikna amaciyla sağlanan menfaatler, örnek olarak bankaya verilen komisyon, ivaz olarak nitelendirilemez (Tandoğan, 1985: 497; Reisoğlu, 1992: 6; Aral, 1997: 239). Çünkü bankanın aldığı bu komisyon,

\footnotetext{
aa Bu hususta örnek olarak A'nın ressam arkadaşı B'nin eserlerinin C tarafından belli bir fiyata alınacağı, aksi takdirde aradaki fark1 kendisinin ödeyeceği şeklindeki anlaşma üçüncü şahsın fiilini taahhüt olup, garanti sözleşmesi olamaz. Bunun gibi garanti verenin, garanti verdiği kişinin fiiline bağlanmayan hususlarda garanti vermesi garanti sözleşmesi olup, üçüncü kişinin fiilini garanti değildir. Örn.gazhane kurulmasında yararı olan bir sanayicinin, bu gazhaneyi kuranlara, her halükarda yılda \%6 temettü dağıtmayı taahhüt etmesi garanti sözleşmesi olarak nitelendirilmiştir. Ayrıntılı bilgi için bkz. Yavuz, 2002: 804.

bb Doktrindeki baskın görüşe göre kefil, ayrıca karalaştırılmadıkça sözleşmenin ortadan kaldırılmasından veya sözleşmeden dönmeden doğan menfi zarararı ödemekle mükellef değildir.bkz. Tandoğan, 1985: 499; Reisoğlu, 1988: 7; Tekinalp, . 397;
} 
kefil banka ile borçlu arasındaki iç ilişkiden doğar, kefalet akdine tamamen yabancıdır (Tandoğan, 1985: 497; Reisoğlu, 1992: 6; Aral, 1997: 239).

Kefilin borcunun tazminat borcu olması sebebiyle asıl borca yabancı bir borç teşkil etmektedir. Kefil, asıl borçlunun ödeme yapmaması halinde alacaklıya yapmış olduğu ödeme, asıl borçlunun borcunu değil kendi borcunu ödemesidir. Böylece kefilin ödeme yapması ile, alacaklının alacağı halefiyet yoluyla kefile geçer (Tandoğan, 1985: 500; Tekinalp, 1988: 398).

Kefaletin, adi kefalet, müteselsil kefalet, kefile kefalet, rücuya kefalet, birlikte kefalet olmak üzere çeşitleri bulunmaktadırcc.

Geçerli bir kefalet sözleşmesinin varlığı için sözleşmenin yazılı olması, alacaklının, borçlunun, kefilin adlarının, borcun nitelik, sebep ve miktarının ayrıca sorumlu olunacak en yüksek meblağın yazılması gerekir (Tandoğan, 1985: 561 ;Reisoğlu, 1992: 113; Yavuz, 2002: 771 ; Zevkliler, 2002: 497; Tekinalp, 1988: 399; Aral, 1997: 247).

Kefil asıl borçla birlikte, kefile dava açılmasını engellemek için yeterli zaman verilmiş, bunun için alacaklı tarafından ihtar edilmiş olması şartıyla dava, takip, avukatlık gibi masraflardan da sorumludur (Tandoğan, 1985: 574). Bunun yanında ancak işlemekte olan ve işlemiş bir yıllık faizi ödemelidir (Tandoğan, 1985: 575.). Burada asıl borç dışındaki ödemelerin kefalet senedindeki en yüksek meblağı aşıp aşmayacağı tartışmalıdır (Tandoğan, 1985: 577).

Kefalet sözleşmesi, asıl borcun ödenmesi, asıl borcu doğuran sözleşmenin feshi, kusursuz imkânsızlık hali, asıl borcun herhangi bir sebeple sona ermesi, kefalet süresinin hitamı, kefalet sözleşmesinin feshi gibi durumlarda son bulur.

\section{c. Kabul Kredisi}

Kabul kredisinde banka, müşterisinin, tarafların karşılaştırdığı bedeli içeren poliçeyi kendi üzerine çekmesine müsaade ettiği ve bu poliçeyi kabul etmeyi taahhüt ettiği gayrinakdi kredi çeşididir (Tekinalp, 1988: 401; Yüksel, 1986: 218). Banka gibi itibarlı bir teminat kurumundan aldığı kabulle bu poliçe, birinci sınıf bir teminata sahip olmakta ve başka bir bankada iskonto ettirilebilir veya ifa amacıyla alacaklıya kolaylıkla verilebilir hale gelir (Tekinalp, 1988: 401). Müşteri, poliçenin vadesinden en geç bir gün önce, poliçe bedelini kabul bankasına yatıracaktır. Bunun üzerine banka da hamile bedeli ödemek suretiyle poliçe ilişkisini sona erdirecektir. Kabul kredisinde banka, kredi alana nakdi bir ödeme yapmamakta, ancak kabul vermek suretiyle müşterisinin elindeki poliçeye güvenilirlik kazandırarak, bu poliçeyle iş yapmasını sağlamaktadır. Bu itibarla banka, müşterisine gayrinakdi kredi sağlamış olur (Tekinalp, 1988: 401).

Kabul kredisi doktrinde baskın görüşe göre iş görme sözleşmesi olarak nitelendirilmektedir. Bankanın poliçeyi kabul edeceğine dair yükümüne eser, müşterinin karşıllı̆ı ve masrafları ödeyeceğine dair sorumluluğuna ise vekâlet sözleşmesi hükümlerinin uygulanacağı ileri sürülmektedir (Tekinalp, 1988: 401).

Bankacılık uygulamasında yaygın olarak, banka poliçeyi kabul ettikten sonra, ayrıca bu poliçeyi iskonto etmektedir. Bu itibarla, banka hem kabul hem de iskonto komisyonu kazanmaktadır (Tekinalp, 1988: 401). İskontoyu ödünç olan nitelendiren yazarlar, doğal olarak

${ }^{c c}$ Bu hususta ayrıntılı bilgi için bkz. Tandoğan, 1985: 561 vd; Reisoğlu, (Kefalet) s. 113 vd; Yavuz, 2002: 778 vd; Zevkliler, 2002: 497 vd; Tekinalp, 1988: 399; Aral, s.252 vd. 
iskontolu kabul kredisini de ödünç olarak nitelendirmektedirler (Tekinalp, 1988: 401). Kanımızca bu durumda bankanın komisyon kazanmakla birlikte, bankanın kendisinin verdiği kabul kredisinin, iskonto veren banka olarak yine kendisine bir teminat fonksiyonu sağlamamaktadır. Ancak zaten kabul kredisi vermekle sorumluluk altına giren banka, iskontoyu da kendisi yaparak komisyonu başka bankaya kazandırmamış olur.

\section{d. Aval Kredisi}

Bankanın, müşterisinin bono veya poliçesine aval vermesi suretiyle, bu senedin sorumluluğunu almasına aval kredisi denir (Tekinalp, 1988: 402; Kölemezli, 1983: 57). Banka, müşterisinin senedine aval vermekle, senedin bedelinden sorumlu olmakta, bu suretle birinci sınıf teminata haiz olan senet, kolaylıkla borca karşılık devredebilmekte ve iskonto ettirilebilmektedir.

\section{e. Ciro Kredisi}

Ciro kredisinde, banka müşterisinin, keşideci veya ciranta yahut kabul eden muhatap olarak, sorumluluk yüklendiği kambiyo senedine cirosunu koymakla, ciro silsilesine katılarak, sorumluluk yüklenmektedir (Kölemezli, 1983:. 58; Tekinalp, 1988: 402). Burada banka tarafından garanti cirosu yapılmaktadır. Bazı yazarlara göre temlik kabiliyeti olmadığından garanti cirosunun geçerli olmadığı bunun ancak aval olabileceği savunulmaktadır. Ancak TTK temlik fonksiyonu olmayan her ciroya imkân vermektedir. Doktrindeki baskın görüş de geçerli olacağı yönündedir (Tekinalp, 1988: 402).

\section{KREDININ AÇILMASI VE İŞLEYIŞ̧i}

\section{1. Kredi Açma Sözleşmesi}

Kredi verme işlemi, kredi açma sözleşmesinin konusunu teşkil etmektedir. Bankalar, kendileriyle ilişki içinde bulunan müşterilerine değişik kredi çeşitleri için çeşitli kredi sözleşmeleri yapmak yerine, müşterileri ile kredi açma sözleşmesi imzalamaktadırlar(Işıktaç, 2001: 43.). Bu itibarla kredi sözleşmesi ile kredi açma sözleşmesini birbirinden ayırmak gerekmektedir. Kredi sözleşmesi tek bir kredi işlemini, kredi açma sözleşmesi ise bir çok kredi sözleşmesini kapsayan çerçeveyi ifade etmektedir (Tekinalp, 1988: 352; Akyol, 2001: 77). Buna göre, kredi açma sözleşmesi; kısmen nakit kredisi, kısmen gayrinakdi kredi olarak kullanabilecektir (Tekinalp, 1988: 352; Işıktaç, 2001: 43; Akyol, 2001: 76).

Kredi açma sözleşmesini; kredi verenin, kredi alana, belirli şartlarla, belirli bir kredi limitine kadar, belirli veya belirsiz bir zaman süreci içerisinde çeşitli türlerde kredi vermeyi, kredi alanın da bankaya karşı aldığını faiz, komisyon ve diğer giderlerle birlikte geri ödemeyi taahhüt etmesi ile kurulan, çerçeve şeklinde bir sözleşme olarak tanımlayabiliriz (Tekinalp, 1988: 352; Iş1ktaç, 2001: 43; Akyol, 2001: 76). Çerçeve sözleşmede, öncelikle taraflar genel bir sözleşme yaparlar, sonrasında bu sözleşmenin edimlerini özel sözleşmelerle ayrıntılı olarak belirleyebilirler (Eren, 2001: 203).

Kredi açma sözleşmesi ile banka en geniş anlamda kredileri müşterisinin kullanımına sunmakta; müşterisinin talebine göre para ödüncü, avans, iskonto gibi nakdi kredi veya kabul, aval, ciro, teminat mektubu gibi gayrinakdi krediler verebilir. 


\section{A. Hukuki Niteliği}

Kredi açma sözleşmesinin hukuki niteliği tartışmalıdır. Bu konudaki görüşleri şu şekilde siralayabiliriz:

\section{a. Ön Ödünç Görüşü}

Bu görüşe göre; kredi açma sözleşmesi, ödünç vaadi sözleşmesi yani ödünç sözleşmesi kurmak üzere yapılmış ön ödünç sözleşmesi olarak nitelendirilmektedir (Tekinalp, 1988: 354; Akyol, 2001: 92.). Kredi açma sözleşmesinin konusu, ödünç sözleşmesi akdetmektir. Bu sözleşmede borç tek taraflı olarak kredi verene yükletilmiştir (Tekinalp, 1988: 354). Bu görüş, kredi alan krediyi kullanmak için ikinci bir sözleşme yapmadığı, tarafların bu sözleşmeyi akdetmekle amaçlarının ikici bir sözleşme yapmak olmayıp, krediyi vermek olması ve sadece nakdi krediyi kapsayacak bir nitelendirme yapılmış olması sebebiyle eleştirilmiştir (Tekinalp, 1988: 354; Akyol, 2001: 92).

\section{b. Rızai Ödünç Görüşü}

Bu görüşe göre; kredi açma sözleşmesi bir rızai akit olan ödünç sözleşmesidir. Bu sözleşme gereğince banka, bir miktar paranın mülkiyetini kredi alana geçirmeyi, kredi alan ise bunu kararlaştırılan şartlard geri ödemeyi taahhüt etmiştir. Sözleşme rızai bir akit olması sebebiyle iradelerin uyuşması ile kurulmakta, ayrıca paranın mülkiyetinin geçirilmesine gerek olmamaktadır. Paranın mülkiyetinin kredi alana geçirilmesi sözleşmenin ifası olup, bunun için ikinci bir sözleşme yapmaya gerek yoktur (Tekinalp, 1988: 354).

Bu görüşe dayalı olarak bir kısım yazara göre ise kredi açma sözleşmesi, ticaret hukukuna özgü değişikliklerle kurulmuş bir ödünç sözleşmesidir (Tekinalp, 1988: 354-355; Akyol, 2001: 92).

Rızai ödünç görüşü de kredi açma sözleşmesini karşılamamaktadır. Şöyle ki; anılan görüş gayri nakdi kredileri kapsamamaktadır (Tekinalp, 1988: 355; Akyol, 2001: 92). Ayrıca ödünç sözleşmesi paranın sözleşme gereğince verilmesini gerektirirken, kredi açma sözleşmesinde kredi alanın emrine hazır bulundurulmaktadır. Kredi açma sözleşmesi bankaya bazı edimler de yükler ki bu ödünç sözleşmesine aykırıdır. Bunların yanında ödünç sözleşmesi paranın geriye ödenmesi ile son bulurken, kredi açma sözleşmesinde banka ile kredi alanın ilişkisi devam etmektedir (Tekinalp, 1988: 355).

\section{c. Çok Aşamalı Sui Generis Sözleşme Görüşü}

Bu grupta yer alan görüşe göre; kredi açma vaadi ve kredinin fiilen verilmesi iki aşama olarak görülmektedir (Akyol, 2001: 92). İlk aşamada çeşitli türden sözleşmelerin dayanağını oluşturan bir genel sözleşme yapılmakta, bundan sonraki aşamalarda ortaya çıkan sözleşmeler ise, kredinin türüne göre, ödünç, satım veya iş görme sözleşmesi niteliği taşırlar (Tekinalp, 1988: 355.). Bu genel sözleşme, kredi alanın krediyi kullanıp kullanmamakta veya hangi tür kredi kullanacağına karar vermekte serbest olması sebebiyle, kredi vereni bağlayan tek taraflı bir sözleşmedir. Kredinin kullanılmasını sağlayan ikinci aşamadaki sözleşmeler, kredi alanın tek taraflı irade beyanı ile geçerlilik kazanırlar (Tekinalp, 1988: 355).

Bazıları ilk aşamadaki ön sözleşmeye temel sözleşme yahut çerçeve sözleşme demektedirler (Tekinalp, 1988: 356; Akyol, 2001: 93). 
Ancak ön sözleşme görüşüne yöneltilen eleştiriler burada da geçerlidir. Kaldı ki; bir sözleşmenin kurulması ile ifası ayrı aşamalar olarak nitelendirilemez (Akyol, 2001: 92).

\section{d. Tek aşamalı Sözleşme Görüşü}

Bu görüşte ise; kredi açma sözleşmesi, kesin nitelik taşıyan iki tarafa borç yükleyen ${ }^{\text {dd }}$, tarafların borç ve yükümlülüklerini belirleyen, çerçeve bir sözleşmedir (Tekinalp, 1988: 356).

$\mathrm{Bu}$ görüşe göre kredi açma sözleşmesinde tek bir borçtan doğan birden fazla karakteristik sözleşmenin edimini ihtiva eden bir çerçeve sözleşme şeklindeki sürekli borç ilişkisi doğuran bir sözleşmedir. Bu sözleşme kredi alana "çekme" hakkı sağlar. Kredi alanın çekme hakkı yenilik doğurucu bir hak olup, seçimlik hakka benzer (Tekinalp, 1988: 356; Akyol, 2001: 94).

Bu görüş kredi açma sözleşmesini daha iyi açıklamakla birlikte, bankacılık uygulamasında, kredi alanın krediyi iskonto, avans, teminat mektubu, aval veya kefalet şeklinde kullanması tarafların mutabakatına bağlı olması sebebiyle tam olarak kredi açma sözleşmesini karşılamamaktadır (Tekinalp, 1988: 357).

\section{B. Kredi Açma Sözleşmesinin Şekli}

Borçlar Hukuku'na hakim olan temel prensipler arasında, şekilsizlik prensibi yer almaktadır. Borçlar Kanununa göre, şekil serbestisi kural, şekle bağlılık istisnadır (Nomer, 2017: 110; Nart, 2014: 22; Eren, 2001: 18). Şekil serbestisi, bir sözleşmenin geçerli olabilmesi için kanunda bir şekil öngörülmediği sürece, sözleşenler irade beyanlarını diledikleri şekilde ortaya koyabilmeleridir. Bu itibarla banka ile kredi alan arasında iradenin uyuşması ile sözleşme kurulmuş olur (Eren, 2001: 248; Tekinay vd., 1993: 99; Işıtaç, 2001: 43; Kostakoğlu, 2003: 751). Kredi açma sözleşmeleri de kanunda özel bir şekil şartına tabi tutulmamıştır (Kostakoğlu, 2005: 751; Tekinalp, 1988: 357; Işıktaç, 2001: 43). Ancak münferit kredi işlemlerinin şekle bağlı olması durumunda bu şekle uymak gerekir. Örneğin kefalet sözleşmesinin geçerliliği yazılı şekilde yapılmasına ve kefilin sorumlu olacağı azami meblağın sözleşmede gösterilmesine bağlıdır (Aral, 1997: 247). Aynı şekilde Tüketicinin Korunması Hakkındaki Kanun m.22/III maddeye göre de tüketici kredisinin yazılı şekilde yapılması, taraflarca imzalanması gerekir. Aksi takdirde geçerli bir sözleşmeden bahsedilemez (Arkan, 1995: 35; İnal, 2002: 211; Yener, 2015: 411).

Bankaların kredi sözleşmelerinin yazılı şekilde yapılması geçerlilik şartı olmamakla birlikte uygulamada ispat açısından sorun yaşanmaması için bütün kredi sözleşmeleri yazılı şekilde yapılmaktadir.

\section{Sözleşmenin İçeriği ve Uygulanacak Hükümler}

Kredi sözleşmesin içeriği, kredi türüne göre şekillenir. Bir kredi sözleşmesi, para ödüncü, senet veya mal avansı, iskonto/ iştira, teminat mektubu, kabul yahut finansal kiralama, forfaitig veya factoring olabilir. Bu itibarla kredi türünün tespiti ile kredi açma sözleşmesine vekalet mi, ödünç mü, satım mı yoksa iş görme sözleşmesinin hükümleri uygulanacak tayin edilir (Tekinalp, 1988: 357-358).

Burada üzerinde durulması gereken bir nokta, kredi açma sözleşmesi ile kredi işleminin birbirinden farklı kavramlardır (Tekinalp, 1988: 357; Akyol, 2001: 76). İkisi arasındaki fark

\footnotetext{
${ }_{\text {dd }}$ Bir taraf belli bir limite kadar krediyi hazır bulundurmayı, diğer taraf ise aldığını faiz ve komisyonuyla geri ödemeyi taahhüt
} eder. 
kendini amaçta gösterir. Kredi açma sözleşmesinin amacı müşterisi için bir limit dâhilinde krediyi onun emrinde hazır bulundurmaktır; kredi işlemi ise kullanılacak kredinin türüne göre sözleşmenin içeriğini belirler (Tekinalp, 1988: 357; Akyol, 2001: 77).

Kredi açma sözleşmesinde tarafların hak ve borçlarını kredinin türü belirler. Ancak bankacılık uygulamasında, genel işlem şartları şeklinde önceden banka tarafından düzenlenmiş olan kredi açma sözleşmeleri tarafların sorumluluklarını tayin etmektedir (Tekinalp, 1988: 358; Işıktaç, 2001: 44).

Kredi sözleşmesinde banka defter ve kayıtlarının delil teşkil etmesine ilişkin delil sözleşmesi olarak nitelendirilebilecek hükümler konulabilir. Bu halde Yargıtay'a göre bir ihtilaf halinde bir iddianın kanıtlanmasında bankanın kayıt ve defterlerinin esas alınacağı öngörülmüşse iddianın başka delillerle ispatı mümkün olamaz (Tekinalp, 1988: 358; Işıktaç, 2001: 44).

\section{Bankaların Genel Kredi Sözleşmeleri ve Genel İşlem Şartları}

Çağımızın sosyal ve ekonomik gelişmeleri, nüfus artışı ve sanayileşme kitlelere yönelik hizmet edimlerini beraberinde getirmiş, bu gelişme sözleşme türlerinde de çeşitlilik yaratmıştır. Buna göre modern toplumlarda bireysel sözleşme yanında, sözleşmenin içeriğini oluşturan şart ve hükümlerin birçoğu önceden hazırlanan genel işlem şartları şeklinde sözleşmeler ortaya çıkmıştır (Nomer, 2017: 78-79; Nart, 2014: 26; Tekinay vd., 1993: 156; Eren, 2001: 203; Kocaman, 2003: 1085-1086).

Genel işlem şartları, bir sözleşenin önceden tek taraflı olarak belirleyip tespit ettiği ve sözleşmenin kurulması esnasında diğer tarafa sunduğu formüle edilmiş şartlara genel işlem şartları denmektedir (Tekinay vd., 1993: 156; Eren, 2001: 204.). BK. 20.madde de "bir sözleşme yapılırken düzenleyenin, ileride çok sayıdaki benzer sözleşmede kullanmak amacıyla, önceden, tek başına hazırlayarak karşı tarafa sunduğu sözleşme hükümleri" olarak tanımlanmıştır.

Burada bir müteşebbisin kitlelere sunmayı planladığı mal ve hizmetlerle ilgili müşterilerle münferit sözleşmeler hazırlamak yerine tek taraflı olarak hazırladıkları standart sözleşmeler yapılmaktadır (Tekinay vd., 1993: 156; Eren, 2001: 204).

Bankalar da müşterileri ile önceden soyut olarak formüle edilmiş şartlar hazırlamak suretiyle, gelecekte banka ile kurulacak belirsiz sayıda, aynı tipteki hukuki işlemleri düzenlemektedir (Kocaman, 2003: 1086). Genel işlem koşulu şeklindeki hükümlerin, sözleşmenin metin kısmında veya ekinde yer alması, kapsamı, yazı türü ve şekli, nitelendirmede önem taşımaz. Aynı amaçla düzenlenen sözleşmelerin metinlerinin özdeş olmaması, bu sözleşmelerin içerdiği hükümlerin, genel işlem koşulu sayılmasını da engellemez (BK. md.20).

Uygulamada sözleşme hükümlerini genel işlem koşulu kapsamından çıkarmak için kredi alanlara "okudum, anladım", "irademe uygundur", "kabul ediyorum" gibi ifadeler yazdırılmaktadır. Genel işlem koşulları içeren sözleşmeye konulan, bu koşulların her birinin tartışılarak kabul edildiğine ilişkin bu türlü kayıtlar, tek başına, onları genel işlem koşulu olmaktan çıkarmaz (BK. md.20/III).

Genel işlem şartları aynı türden işler için farklı hükümler içeren sözleşmeler yapılmasını, özellikle bir kitleye hizmet veren kuruluşlar bakımından münferit sözleşmeler yapılmasını engellemesi açısından pratiktir. Bu bakımdan aynı türden çeşitli hizmetler veren bankanın 
genel işlem şartları olmaksızın sözleşme yapması mümkün değildir (Kocaman, 2003: 1087). Ancak genel işlem şartları ile ekonomik açıdan güçlü taraf lehine eşitlik bozulmakta, taraflardan birinin dikte ettirdiği şartlar diğer tarafın sözleşme özgürlüğünü ortadan kaldırmakta, sözleşenler arasında eşitsizlik doğmaktadır (Kocaman, 2003: 1087; İnal, 2002: 138). Çünkü genelde bankalar gibi genel işlem şartları kullanan kurumlar, yapılacak işten doğabilecek tüm riskleri, karşı tarafa yükleyecek şekilde hükümler koymaktadırlar (Kocaman, 2003: 1086).

Genel işlem şartları, emredici hükümlere aykırı düzenlenemez, emredici hukuk kurallarını ortadan kaldıramazlar. Buna karşılık genel işlem şartlarını düzenleyenler her konuyu ayrıntısına kadar düzenlemekle, sözleşmede hüküm bulunmayan hallerde her iki tarafın menfaatine olan tamamlayıcı hukuk kurallarının uygulanmasına yer bırakmamaktadırlar (Tekinay vd., 1993: 160; Eren, 2001: 206; Kocaman, 2003: 1087).

\section{E. Genel İşlem Şartlarının Denetlenmesi}

Genel İşlem şartların kullanılması, sözleşenin sözleşmeye müdahale olanağını yitirmesi ve bu nedenle sözleşme adaletinin müşteri aleyhine bozularak, sözleşme özgürlügünün zedelenmesi sebebiyle Borçlar Kanunu 20 vd. maddelerinde açıkça düzenlenmiştir. BK. md.21 de genel işlem koşulunun yaptırımı olarak bu kapsamdaki maddelerin yazılmamış sayılması şeklinde bir çözüm tarzı benimsenmiştir. Karşı tarafın menfaatine aykırı genel işlem koşullarının sözleşmenin kapsamına girmesi ancak sözleşmenin yapılması sırasında düzenleyenin karşı tarafa, bu koşulların varlığı hakkında açıkça bilgi vermesi ve bunların içeriğini öğrenme imkânı sağlamasına ve karşı tarafın da bu koşulları bu şekilde kabul etmesine bağlıdır. Aksi takdirde, genel işlem koşulları yazılmamış sayılır (BK. md.21).

Burada üzerinde durulması gereken bir başka husus ise kredi alanın tacir olması durumunda genel işlem şartlarının ezici hükümlerine karşı bir korumadan faydalanıp faydalanamayacağıdır. Bilindiği üzere tacir olmanın sonuçlarından biri olarak TTK. 18/II. maddede ticaretine ilişkin tüm faaliyetlerinde basiretli bir iş adamı gibi davranma yükümlülüğ̈̈ sayılmıştıree. Bu itibarla bir tacirin akdettiği kredi açma sözleşmesindeki şartların muhasebesini yapması beklenecektir. Bunun yanında tacirlerin serbest piyasa ortamında, tüketicilere oranla daha avantajlı oldukları, hatta kredi açma sözleşmesindeki genel işlem şartları sebebiyle uğradıkları zararları üçüncü kişilere ve bu arada tüketicilere yansitabilecekleri de söylenmektedir (Kocaman, 2003: 1096). Ancak bir tacir için, bankadan kredi almak çoğu zaman bir zorunluluk arz etmektedir (Akyol, 2001: 97). Bu itibarla, tacirin kredi alma zorunluluğu içinde bulunması sebebiyle ve bunun baskısı altında imzaladığı genel işlem şartlarının hukuk düzeni tarafından korunmalıdır. Ayrıca Anayasa 173. maddesi ile devlete aynı tüketicileri olduğu gibi, esnaf ve sanatkârları da koruma yükümünün bulunduğundan, tacirler açısında da bir tehlike oluşturan genel işlem şartlarına karşı onları korunmasız birakmak yerinde olmayacaktır (Kocaman, 2003: 1096; Nomer: 2017: 179). Bu itibarla belli ölçüde, tacirler açısından da genel işlem şartlarının, sözleşme özgürlüğünün genel sınırlarına takılması düşünülebilir (Kocaman, 2003: 1096.).

\footnotetext{
ee Basiretli Bir İşadamı Gibi Davranma Yükümlülüğü hakkında bkz. Bahtiyar, 2010: 77-79; Bilgili, Demirkapı, 2012: 93-94; Bilgili, Demirkap1, 2012: 61-62.
} 


\subsection{Kredi Hesabı ve İşleyişi}

Banka ile bir gerçek veya tüzel kişi arasında kredi ama sözleşmesi imzalanması suretiyle kredi ilişkisi doğmaktadır. Bu kredinin ne şekilde kullanılacağı, ne şekilde ödeneceği gibi hususlar, kredinin işleyeceği hesabın türüne göre değişir. Buna göre krediler, avans veya borçlu cari hesap şeklinde açılabilir.

\section{A. Borçlu Cari Hesap Şeklinde Açılan Krediler}

Cari hesap, TTK. m. 89/I 'da; “iki kişinin herhangi bir hukuki sebep veya ilişkiden doğan alacaklarını teker teker ve ayrı ayrı istemekten karşılıklı olarak vazgeçip bunları kalem kalem alacak ve borç şekline çevirerek hesabın kesilmesinden sonra çıkacak artan tutarı isteyebileceklerine ilişkin sözleşme cari hesap sözleşmesidir" şeklinde tanımlanmıştır. Cari hesap sözleşmesi en yaygın şekilde bankalarla müşterileri arasında uygulanmaktadır (Poroy ve Yasaman, 2001: 227-229).

Cari hesap bankacılık uygulamasında alacaklı cari hesap ve borçlu cari hesap olmak üzere ikiye ayrılır (Tekinalp, 1988: 319). Alacaklı cari hesap, gerçek veya tüzel kişilerin, bankaya mevduat yatırmak suretiyle açtırdıkları, sadece para yatırma, çekme, havale yapmak ve çek kullanmayı sağlayan, müşterinin mevduat bakiyesi kadar hep alacaklı olduğu cari hesaptır(Tekinalp, 1988: 319). Asıl inceleyeceğimiz hesap türü olan borçlu cari hesap ise; bankanın müşterisinin kullanımına tahsis ettiği kredinin bulunduğu hesaptır (Tekinalp, 1988: 319). Bankacılık tekniği açısından borçlu cari hesap terimi, cari hesap hükümlerine tabi olarak açılan kredileri ifade etmektedir (Küney, 1986: 21). Müşteri bu hesabı çeşitli nakdi veya gayri nakdi kredileri kullanmak üzere açtırmaktadır.

Cari hesap şeklinde açlan kredide kredi alan, belli bir limit içerisinde, ihtiyacı olduğu zamanda, ihtiyacı olduğu kadar kredi kullanabilmek suretiyle ihtiyacı olduğu oranlarda borçlanmış ve bu orana isabet eden faizi ödemiş olmaktadır (Toköz, 1976: 77). Bu açıdan ileride anlatacağımız avans kredisinden daha kullanışlı olmaktadır.

Burada banka müşterisi, kredi alıp bunu geri ödeyip tekrar almak suretiyle krediyi döner şekilde kullanabilmektedir.

Cari hesap ilişkisi içinde borçlar ve alacaklar nakden ödeme yerine hesaben ödenmektedir (Küney, 1986: 21; Bilgili ve Demirkapı, 2012: 147-148 ). Cari hesap dönemi sonunda belirlenen bakiyeye, cetveli alan taraf, aldığı tarihten itibaren bir ay içinde, noter aracılığıyla, taahhütlü mektupla, telgrafla veya güvenli elektronik imza içeren bir yazıyla itirazda bulunmamışsa, bakiyeyi kabul etmiş sayılır (TTK. 94/II).

Borçlu cari hesabın hukuki niteliği tartışmalıdır. Yargıtay bir kararında cari hesap sözleşmesinin ayırıcı niteliğinin "karşılıklı alacaklı ve borçlu olmak" şeklinde olduğunu belirleyerek, borçlu cari hesap şeklindeki sözleşmelerde müşterinin her zaman borçlu olduğundan bahisle ortada bir cari hesap değil, karz akdi olduğunu belirtmiştirff. Doktrinde, karşılıklılığın sadece hukuki bir anlam taşıdığı, tarafların fiilen alacaklı ve borçlu olabilme imkânlarının bulunmasının yeterli olduğu öne sürülerek bu karar eleştirilmiştir (Tekinalp, 1988: 319; Reisoğlu, 1988: 280; Bahtiyar, 2010:165). Ayrıca müşteri aldığı krediden fazlasını yatırarak alacaklı duruma da gelebilir. Zaten müşteri sürekli borçlu olsa bile, müşteri ile banka

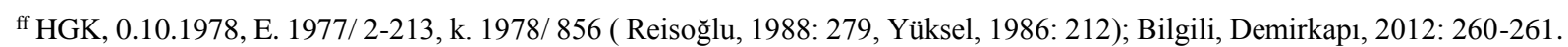


arasındaki sözleşmenin karz akdi olarak nitelendirilmesi mümkün değildir. Çünkü karz akdinde alınanın geri ödenmesi ile sözleşme sona ererken bu ilişkide müşteri aldığı krediyi yatırıp tekrar çekmek suretiyle krediyi döner (rölatif) olarak kullanabilmekte, bunlar matlup ve zimmet kaydedilmek suretiyle banka ile müşterisinin ilişkisi karz akdinin aksine devam etmektedir (Reisoğlu, 1988:280).

Cari hesap muamelelerinde banka, müşterisinin ileride durumunun kötüleşmesi, aldığ1 kredileri ödeyememesi gibi durumları göz önünde tutarak, banka sözleşmeyi bozma hakkını muhafaza etmektedir (Toköz, 1976: 77).

\section{B. Avans Şeklinde Açılan Krediler}

Avans şeklinde açılan kredilerde, bankalar tarafından verilen kredilerde, alınan kredinin bir defada veya taksitler halinde, belli bir vadede ödenmesi kararlaştırılmaktadır (Kostakoğlu, 1996: 106; Reisoğlu, 1988: 283; Küney, 1986: 25). Banka ile müşterisi arasında avans şeklinde işleyen kredi hesabı açılması için yapılan sözleşme karz akdi niteliğindedir (Reisoğlu, 1988: 283).

Avans şeklinde açılan kredilerde, kredi döner (rölatif) şekilde kullandırılmaz. Müşteri krediyi bir defada alır ve belirlenen vadede tek veya taksitler halinde ödenir (Küney, 1986: 26). Ödeme yapıldıktan sonra muamelenin tekrarlanıp tekrarlanmayacağı yeniden kararlaştırılır(Küney, 1986: 26).

\section{KREDİ SINIRLARI}

\section{1. Genel Olarak}

Bankalar para, kredi, mevduat ve sermaye piyasasında faaliyet göstermek ve bankacılık hizmetleri vermek üzere kurulmaktadırlar. Bankaların kredi ve sermaye piyasalarında var olabilmesi yeterli mali kaynaklara sahip olmasını gerektirir. Bankaların kaynaklarını sermaye ve yedek akçelerden oluşan özkaynaklar ile en başta mevduat olmak üzere çeşitli yabancı kaynaklar teşkil etmektedir (Kölemezli, 1983: 209). Bankalar, özkaynaklarını ve yabancı özkaynak olarak topladıkları mevduatları kredi olarak kullandırmaktadırlargg. Kredi, banka açısından esasen bir riski ifade etmektedir. Yeterli teminatı ya da karşılığı olmayan risklerin artması, bankaların kredi olarak verdikleri meblağları kaybetmelerine ve bunun sonucu olarak ödeme gücü ve likiditenin azalarak mali yapısının bozulmasına neden olacaktır(Battal, 2003: 110). Bankaların likidite ve ödeme güçlerinin belirlenmesinde öz kaynaklar merkezi rol oynamaktadır. Bu bağlamda bankanın riskli faaliyetleri, özkaynaklara oranlanarak sınırlandırılmaktadır (Altay, 2002: 10). Bu itibarla kredi sınırlarına geçmeden önce öz kaynak terimi ve hesaplanışı üzerinde durmak yerinde olacaktır.

\section{2. Özkaynak Kavramı}

Bankaların Kuruluş ve Faaliyetleri Hakkında Yönetmelik ${ }^{\text {hh }}$ 4. maddesinde özkaynağı, “Özkaynak, ay sonları itibarıyla hesaplanmak üzere, bankaların ana sermaye ve katkı sermayeleri toplamından, sermayeden indirilen değerlerin düşülmesi sonucu bulunacak

gg Battal, Ahmet: Bankalar Kanunu Şerhi Sorularla Banka Hukuku, Ankara 2003, s. 110. Anonim şirketlerin bilançoları açısından bilançonun aktif tarafı varlıkları, pasif tarafı ise bu varlıkların kaynağını oluşturur. Bu itibarla anonim şirket olarak kurulan bankaların özkaynak ve yabancı kaynakları pasif tarafta, bankanın kredi vermek suretiyle yaptığı yatırımları ise aktif kısımda değerlendirebiliriz. Bkz. Poroy, Tekinalp, Çamoğlu, 2000: 737 vd.

hh RG.27.06.2001, S. 24445. 
tutarı ifade eder" şeklinde tanımlamıştır. Aynı maddeye göre özkaynak; ana sermaye, ödenmiş sermaye, kanuni, ihtiyari ve fevkalade yedek akçeler, vergi karşılığından sonraki dönem kârı ve geçmiş yıllar kârı toplamından oluşmaktadır. Ana sermayenin hesaplanmasında, bankaların dönem zararı ile geçmiş yıllar zararı toplamı indirim kalemi olarak dikkate alınmaktadır.

\subsection{Kredi Sinırları}

Kredi sınırları 5411 sayılı Bankacılık Kanunu'nun 54. maddesinde düzenlenmiştir. Bu madde ile öncelikle kredi tanımı ve kapsamı saptanmıştır. Bu maddeye göre vadeli işlem ve opsiyon işlemleri ${ }^{i i}$ de kredi kapsamında değerlendirilmiştir. Bu işlemlerle bankanın alacaklı duruma gelmesi çoğunlukla gayrinakdi kredi niteliğindedir (Battal, 2003: 114).

Aynı maddenin 1. fıkrasında kredi limiti düzenlenmiştir. Buna göre bir banka, gerçek veya tüzelkişiye ya da bir risk grubuna doğrudan veya dolaylı olarakij özkaynaklarının yüzde yirmi beşinden fazla kredi veremez, aval ve kefaletlerini kabul edemez. Buna genel kredi sınırı denilmektedir. Bankaların kredi açma limitinin hesabında, kredi işleminin yapılacağı tarihten önceki ayın sonunda hesaplanmış öz kaynak esas alınmaktadır.

Birlikte kontrol edilen ortaklıklara kullandırılan krediler, bu ortaklıkları birlikte kontrol eden hissedarların her birinin ortaklık sermayesinde sahip olduğu payların, birlikte kontrol ettikleri toplam paya oranı ölçüsünde ortaklığı birlikte kontrol eden her bir hissedarın dâhil olduğu risk grubuna kullandırılmış sayılır (Bankacılık Kanunu 54/III). Adi ortaklıklara kullandırılan krediler bakımından ise; adi ortaklığın tüzel kişiliği olmadığından, her bir ortak payı oranında kredi almış sayılır (Kostakoğlu, 2003: 271).

Bunun yanında Bankacılık Kanunu 54/IV de büyük kredi tanımlanmış ve kredi sınırı tespit edilmiştir. Buna göre; bir gerçek ya da tüzel kişiye veya bir risk grubuna özkaynakların yüzde onu veya daha fazlası oranında kullandırılan krediler büyük kredi sayılır ve bunların toplamı özkaynakların sekiz katını aşamaz.

5411 sayılı Bankacılık Kanunu'nun 55.maddesinde, 54.maddedeki sınırlamalara tabi olmayan kredi işlemlerini saymıştır. Buna göre;

a) Karşılığı nakitkk, nakit benzeri kıymet ve hesaplar ile kıymetli maden olan işlemler.

b) Hazine Müsteşarlığı, Merkez Bankası, Özelleştirme İdaresi Başkanlığı ve Toplu Konut İdaresi Başkanlığıyla yapılan işlemler ile bu kurumlarca çıkarılan ya da ödenmesi garanti edilen bono, tahvil ve benzeri menkul kıymetler karşılı̆̆ı yapılan işlemler.

c) Merkez Bankası nezdindeki piyasalarda veya kanunla teşkilatlanmış diğer para piyasalarında yapılan işlemler.

d) Aynı kişiye ya da aynı risk grubuna yeni kredi tahsisi hâlinde daha önce yabancı para cinsinden veya yabancı para ölçüsü ile verilen kredilerin, müteakiben tahsis edilen

\footnotetext{
${ }^{i i} \mathrm{Bu}$ tür sözleşmelerde bir taraf opsiyon yani seçimlik hak sahibi olup, diğer taraf ise kesin taahhütte bulunmaktadır. Opsiyon hakkına sahip olan taraf, kesin taahhütte bulunan tarafa komisyon veya prim adı altında bir ödemede bulunmaktadır. Bkz. Kostakoğlu, Şerh, s. 269.

jj Dolaylı kredi , bir gerçek veya tüzel kişiye açılan, ancak, kanunda öngörülen şartların varlığı halinde, kredi sözleşmesinin tarafını teşkil etmemesine rağmen bir üçüncü kişi veya kişilere de açılmış sayılan kredidir. Bkz. Tekinay, s. 159.

kk Karşılığı nakit olan krediler, bankanın krediyi karşılayacak miktarda nakit parayı, tam bir teminat oluşturacak şekilde kasasında tutmaktadır. Bkz. Battal, 2003: 118.
} 
kredinin kullandırılmaya başlandığı tarihteki cari kurdan dikkate alınması kaydıyla çek ve kredi kartı kullandırımları hariç, kredilerde kur değişikliklerinin doğurduğu artışlar ile vadesi geçmiş kredilere tahakkuk ettirilen faiz, kâr payı ve diğer unsurlar.

e) Her türlü sermaye artırımları dolayısıyla bedelsiz edinilen ortaklık payları ile ortaklık paylarının herhangi bir fon çıkışı gerektirmeyen değer artışları.

f) Kurulca belirlenecek esaslar dâhilinde bankaların kendi aralarındaki işlemler.

g) Kurulca belirlenecek esas ve süreler çerçevesinde elden çıkarılması kaydıyla halka arza aracılık yüklenimleri kapsamında edinilen ortaklık payları.

h) Özkaynak hesabında indirilecek değer olarak dikkate alınan işlemler.

i) Kurulca belirlenecek diğer işlemler.

\subsection{Yasak Kredi İşlemleri}

Bankalar Kanunu tarafından bazı kişilere kredi verilmesi yasaklanmıştır. 5411 sayılı Bankacılık Kanunu'nun 50.maddesinde kredi işlem yasakları ve istisnaları sayılmıştır. Buna göre, bankalar;

a) Yönetim kurulu üyelerine, genel müdüre, genel müdür yardımcılarına ve kredi açmaya yetkili mensuplarına; bunların eş ve velâyet altındaki çocuklarına; tek başlarına ya da birlikte sermayesinin yüzde yirmibeş veya fazlasına sahip oldukları ortaklıklara,

b) (a) bendinde sayılanlar dişında kalan mensupları ile bunların eş ve velâyeti altındaki çocuklarına,

c) Mensuplarının kurduğu veya bunlar için kurulan sandık, dernek, sendika veya vakıflara,

Her ne şekil ve surette olursa olsun nakdî ve gayrinakdî kredi veremez, tahvil ya da benzeri menkul kıymetlerini satın alamazlar.

Birinci fıkra hükümleri, yönetim kurulu üyeliklerinde aslen bulunan veya temsilci bulunduran ve banka sermayesinde doğrudan veya dolaylı olarak nitelikli paya sahip olan gerçek kişi ortaklar ile tüzel kişi ortaklar hakkında uygulanmaz.

Bir bankanın ortaklıklarının yönetim ve denetim kurullarında bulunan kimselerin aynı zamanda ilgili bankanın mensubu olması, bu ortaklıkların ilgili banka ile işlem yapmasına engel değildir.

Bankanın dâhil olduğu risk grubunda bulunan gerçek ve tüzel kişilere kredi kullandırılması hâlinde, gerekli kararların yönetim kurulunun üye tam sayısının üçte iki çoğunluğu ile alınması ve bunlara sağlanan kredi koşullarının kredi kullananın lehine diğer kişi ve gruplara kullandırılanlardan ve piyasa koşullarından farklılık arz etmemesi şartıır.

Bir bankanın yönetim kurulu üyelerine, mensupları ile bunların eşlerine ve velâyet altındaki çocuklarına, aylık net ücretleri toplamının beş katını aşmamak üzere verilecek krediler, üç katını aşmamak üzere çek karnesi veya kredi kartı verilmesi suretiyle kullandırılacak krediler ile 5411 sayılı Kanunun 55 inci maddesinin (a) ve (b) bentlerinde belirtilen menkul kıymetler karşılığı kullandırılan krediler birinci ve dördüncü fıkra hükümlerine tâbi değildir. 
Banka, bankanın risk grubunda yer alan kişilere açtı̆̆ı kredileri Kuruma düzenli olarak raporlar. Sonradan bu madde hükümlerine aykırı hale gelen kredilerin en geç altı ay içinde tasfiye edilmesi zorunludur.

\section{KREDİ İLISSKISIININ SONA ERMESİ}

Kredi açma sözleşmesi ile kurulmuş olan kredi ilişkisi, kredi sözleşmesindeki sürenin dolması, fesih, iradeyi sakatlayan sebeplerden birinin varlığı halinde sözleşmenin iptali gibi sebeplerle son bulur.

Bankalar genellikle kredi sözleşmelerine, sözleşmeyi herhangi sebep, süreye bağlı olmadan feshedebileceklerine dair hüküm koymaktadırlar. Ancak feshin MK. madde 2' ye aykırı olması durumunda, sorumluluk bankaya ait olacaktır (Tekinalp, 1988: 358).

\section{SONUÇ}

Kredi, satın alma gücünün, belli bir süre sonra ödenmek vaadiyle, bir bedel karşılığında bir başkasının kullanımına bırakılmasıdır. Bu tanıma göre kredinin unsurlarını; maddi veya maddi olmayan bir malın verilmesi veya risk için sorumluluk yüklenilmesi şeklinde belli bir satın alma gücünün kredi veren tarafından sağlanması, kredinin belli bir süre için, bu süre sonunda iade edilmek için verilmesi, kredinin iade edileceği vaadine yönelik güven ve bedel (faiz) olarak sayabiliriz.

Krediler nitelikleri açısından nakdî kredi ve gayri nakdî kredi olarak ikiye ayrılır. Nakdi krediler, banka tarafından nakit ödeme yapılmak suretiyle verilen krediler nakdi kredilerdir. Gayri nakdi krediler (yükümlülük kredisi - sorumluluk kredisi) ise; bankanın para ödemeksizin bir riskin gerçekleşmesi halinde, ortaya çıkacak olan zararın sorumluluğunu üstlendiği kredilerdir.

Nakdi krediler; Sabit Vadeli Para Ödüncü, Senet veya Emtia Avansı (Lombard Kredisi), Kıymetli evrakın iskontosu ve İştiraı Yolu ile Kredi Verilmesi, Forfait (Uzun Vadeli Alacak Satın Alınması) İşlemi ile Kredi Verilmesi, Factoring (Alacak Satın Alınması ve Takibi) İşlemi ile Kredi Verilmesi, Finansal Kiralama ( Leasing ) İşlemi İle Kredi Verilmesi olarak sayılabilir.

Nakit kullanımı söz konusu olmayan gayri nakdi krediler (yükümlülük kredisi- sorumluluk kredisi ); Garanti Kredisi, Kefalet Kredisi, Aval Kredisi, Ciro Kredisi olarak sayılabilir.

Kredi ilişkisi, Banka ile kredi alan arasında akdedilen bir sözleşmeyle kurulur. Bu sözleşme kredi sözleşmesi ve kredi açma sözleşmesi olarak ikiye ayrılır. Kredi sözleşmesi tek bir kredi işlemini, kredi açma sözleşmesi ise birçok kredi sözleşmesini kapsayan çerçeve sözleşmeyi ifade eder. Kredi açma sözleşmesi ile banka, kredi çeşitlerini müşterisinin kullanımına sunmakta; müşterisinin talebine göre para ödüncü, avans, iskonto gibi nakdi kredi veya kabul, aval, ciro, teminat mektubu gibi gayrinakdi krediler verebilmektedir. Tüketici kredisinde olduğu gibi istisnalar dışında kredi açma sözleşmeleri kanunda özel bir şekil şartına tabi tutulmamıştır. Ancak bankacılık uygulamasında ispat açısından kredi ve kredi açma sözleşmeleri yazılı şekilde yapılmaktadır.

Kredi sözleşmesinin hükümleri kredi türüne göre şekillenir. Bir kredi veya kredi açma sözleşmesi; para ödüncü, senet veya mal avansı, iskonto/ iştira, teminat mektubu, kabul yahut finansal kiralama, forfaitig veya factoring şeklinde kredi türlerine ilişkin olabilir. Bu nedenle kredi türünün tespit edilmesi ile bu sözleşmenin işleyiş̧i açısından kredi açma sözleşmesine 
vekalet mi, ödünç mü, satım mı yoksa iş görme sözleşmesinin hükümleri mi uygulanağ1 belirlenecektir.

Bankaların müşterileri ile önceden soyut olarak formüle edilmiş şartlar hazırlamak suretiyle, gelecekte banka ile kurulacak belirsiz sayıda, aynı tipteki hukuki işlemleri düzenlemeleri sebebiyle kredi ve kredi açma sözleşmeleri katılmalı (iltihaki) sözleşmeler olarak ortaya çıkar. $\mathrm{Bu}$ sözleşmelerde yer alan genel işlem koşulları Borçlar Kanunu 20 ve devamı maddelerinde düzenlenen, sözleşmenin karşı tarafını koruyucu emredici hükümlere tâbidir.

Kredinin ne şekilde kullanılacağı, ne şekilde ödeneceği gibi hususlar, kredinin işleyeceği hesabın türüne göre değişir. Buna göre krediler; borçlu cari hesap veya avans şeklinde açılabilir. Bankacılık uygulamasında, kredi açısından kullanılan hesap türü olan borçlu cari hesap; bankanın müşterisinin kullanımına tahsis ettiği kredinin bulunduğu hesaptır. Borçlu cari hesap terimi, cari hesap hükümlerine tabi olarak açılan kredileri ifade eder. Borçlu cari hesap, müşteri tarafından çeşitli nakdi veya gayri nakdi kredileri kullanmak için açtırılmaktadır. Burada banka müşterisi, kredi alıp bunu geri ödeyip tekrar almak suretiyle krediyi döner şekilde kullanabilmektedir. Borçlu cari hesabın hukuki niteliğini, Yargıtay bir kararında cari hesap sözleşmesinin ayırıcı niteliğinin "karşılıklı alacaklı ve borçlu olmak" şeklinde olduğunu belirleyerek, borçlu cari hesap şeklindeki sözleşmelerde hiçbir zaman müşterinin her zaman borçlu olduğundan bahisle ortada bir cari hesap değil, karz akdi olduğunu belirtmiştir. Bizim de katıldığımız doktrindeki bu kararı eleştiren görüşlere göre ise; karşılıklılığın sadece hukuki bir anlam taşıdığı, tarafların fiilen alacaklı ve borçlu olabilme imkânlarının bulunmasının yeterli olduğu, en önemlisi ise müşteri aldığı krediyi yatırıp tekrar çekmek suretiyle krediyi döner (rölatif) olarak kullanabilmesi sebebiyle cari hesap sözleşmesi karz akdi olarak kabul edilemez. Karz akdinde, alınanın geri ödenmesi ile sözleşme sona erer.

Avans şeklinde açılan kredilerde, alınan kredinin bir defada veya taksitler halinde, belli bir vadede ödenmesi kararlaştırılmaktadır. Bu kredinin hukuki niteliği karz akdidir.

Bankaların korunabilmesi için 5411 sayılı Bankacılık Kanunu'nun 54. Maddesi ile kredi sınırı getirilmiştir. Buna göre; bir banka, gerçek veya tüzelkişiye ya da bir risk grubuna doğrudan veya dolaylı olarak özkaynaklarının yüzde yirmi beşinden fazla kredi veremez, aval ve kefaletlerini kabul edemez. Buna genel kredi sınırı denilir. Bunun yanında Bankacılık Kanunu 54/IV hükmüne göre; bir gerçek ya da tüzel kişiye veya bir risk grubuna özkaynakların yüzde onu veya daha fazlası oranında kullandırılan krediler, büyük kredi sayılır ve bunların toplamı özkaynakların sekiz katını aşamaz.

Bankalar Kanunu tarafından bazı kişilere kredi verilmesi yasaklanmıştır. 5411 sayılı Bankacılık Kanunu'nun 50. maddesinde kredi işlem yasakları ve istisnaları sayılmıştır. Buna göre; bankalar;

a) Yönetim kurulu üyelerine, genel müdüre, genel müdür yardımcılarına ve kredi açmaya yetkili mensuplarına; bunların eş ve velâyet altındaki çocuklarına; tek başlarına ya da birlikte sermayesinin yüzde yirmibeş veya fazlasına sahip oldukları ortaklıklara,

b) (a) bendinde sayılanlar dışında kalan mensupları ile bunların eş ve velâyeti altındaki çocuklarına,

c) Mensuplarının kurduğu veya bunlar için kurulan sandık, dernek, sendika veya vakiflara, 
Her ne şekil ve surette olursa olsun nakdî ve gayrinakdî kredi veremez, tahvil ya da benzeri menkul kıymetlerini satın alamazlar.

Birinci fıkra hükümleri, yönetim kurulu üyeliklerinde aslen bulunan veya temsilci bulunduran ve banka sermayesinde doğrudan veya dolaylı olarak nitelikli paya sahip olan gerçek kişi ortaklar ile tüzel kişi ortaklar hakkında uygulanmaz.

Kredi açma sözleşmesi ile kurulmuş olan kredi ilişkisi, kredi sözleşmesindeki sürenin dolması, fesih, iradeyi sakatlayan sebeplerden birinin varlığı halinde sözleşmenin iptali gibi sebeplerle son bulur.

\section{KAYNAKÇA}

Akyol, Ş. (2001). Banka Sözleşmeleri, Ord. Prof.Dr. Kemalettin Birsen'e Armağan, Borçlar Hukuku Özel Borç İlişkileri , 3.Fasikül. İstanbul.

Altay, S. A. (2002). 4672 Sayılı Kanun'un Bankaların Yeniden Yapılandırılmasına ve Tasfiyesine ilişkin Sistem Üzerinde Etkisi. Prof.Dr.Ömer Teoman'a 55. Yaş Günü Armă̆anı, C.I, İstanbul.

Aral, F. (1997). Borçlar Hukuku Özel Borç İlişkileri. Ankara.

Arkan, S. (1995). “Tüketici Kredileri”, Batider C.XVIII, S.1-2.

Bahtiyar, M. (2010). Ticari işletme Hukuku, 9.B. İstanbul.

Battal, A. (2003). Bankalar Kanunu Şerhi Sorularla Banka Hukuku. Ankara.

Bilgili, F., \& Demirkapı, E. (2012). Ticari işletme Hukuku, 3.B. Bursa.

Eren, F. (2001). Borçlar Hukuku Genel Hükümler, VII.Bası. İstanbul.

Etem, M. (1934): Kredi-Banka - Borsa Notlar, İstanbul.

Işıktaç, M. Ş. (2001). Uygulamada Bankacılar İçin Hukuku.

İnal, T. (2002). Açıklamalı - İçtihatlı Tüketici Kredileri ve Tüketici Kredisi Sözleşmeleri İsviçre Hukuku - Fransız Hukuku ve Avrupa Birliği Konseyi Yönergeleri Işı̆̆ında. İstanbul.

Kahyaoğlu, H. Ş. (1969). Para - Kredi - Banka - Kambiyo. İzmir.

Karacan, İ. (1987). Bankacılık Hukuku, Cilt I.

Kocaimamoğlu, S. Bankacılık ansiklopedisi.

Kocaman, A. (2003). Bankaların Tacir ve Sanayiciler ile Yapmış Oldukları Genel Kredi Sözleşmelerindeki Genel İşlem Şartlarının Hukuki Açıdan Değerlendirilmesi Ve Çözüm Önerileri. Ünal Tekinalp'e Armağan, C.I. İstanbul.

Kostakoğlu, C. (1996). Banka Kredi Sözleşmelerinden Doğan Uyuşmazlıklar, II. Bası. İstanbul.

Kostakoğlu, C. (2003). Bankalar Kanunu Şerhi Banka Kredi Sözleşmelerinden doğan Uyuşmazlıklar ve Akreditif, IV. Bası. İstanbul. 
Köteli, A. (1983). Leasing Sözleşmelerinin Hukuksal ve Mali Yönleri ile Türkiye'de Uygulanabilirliliği. Batider, C.XII, S.1.

Küney, H. (1986). Banka Tekniği, V. Bası. Ankara.

Nart, S. (2014). Borçlar Hukuku. Ankara.

Nomer, H. N. (2017). Borçlar Hukuku Genel Hükümler, 15.B. İstanbul.

Onur, V. (1957). Bankalarda Ticari Krediler ve Başka Hizmet Muameleleri, Ankara.

Poroy, R., Yasaman, H. (2001). Ticari İşletme Hukuku, IX. Bası. İstanbul.

Poroy, R., Tekinalp, Ü., \& Çamoğlu, E. (2003). Ortaklıklar ve Kooperatif Hukuku, VIII.Bası. İstanbul.

Poroy, R. (1999). Kıymetli Evrak Hukuku Esasları, XI.Bası. İstanbul.

Reisoğlu, S. (1988). 3182 sayılı Bankalar Kanunu Şerhi, Ankara.

Reisoğlu, S. (1992). Türk Hukukunda ve Bankacılık Uygulamasında Kefalet. Ankara. (Anılış: Kefalet).

Tandoğan, H. (1985). Borçlar Hukuku, Özel Borç İlişkileri, C.1/2, III. Bası, Ankara.

Tekinalp, Ü. (1988). Banka Hukukunun Esasları. İstanbul.

Tekinay, S. S., Akman, S., Burcuoğlu, H., \& Altop, A. (1993). Borçlar Hukuku Genel Hükümler, VII. Bası, İstanbul.

Toköz, N. H. (1976). Bankacılı̆̆ın Genel İlkleri. Ankara.

Tunçomağ, K. (1985). Borçlar Hukuku Özel Borç İlişkileri Akdin Muhtelif Nev'ileri, II. Bası, C.II, İstanbul.

Urganc1, H. (1982). Para ve Banka. Adana.

Yavuz, C. (2002). Türk Borçlar Hukuku Özel Hükümler, VI.Bası. İstanbul.

Yener, M. D. (2015). 6502 Sayılı Yeni Tüketicinin Korunması Hakkındaki Kanunun Tüketici Kredileri Bakımından Getirdiği Yenilikler, Finansal Araştırmalar ve Çalışmalar Dergisi, Cilt 7, Sayı 13.

Y1lmaz, E. (1992). Hukuk Sözlü̈̆̈̈̈, 4.B. Ankara.

Yüksel, A. S. (1986). Bankacılık Hukuku ve İşletmesi, V.Bas., İstanbul.

Zarakoğlu, A. (1972). Bankacılar İçin Para ve Kredi Bilgisi, III. Bası. Ankara.

Zevkliler, A. (2002). Borçlar Hukuku Özel Borç İlişkileri, VII.Bası. Ankara. 